\title{
Geographies of Origin and Proximity: Approaches to Local Agro-Food Systems
}

\author{
Javier Sanz-Cañada ${ }^{1}$ and José Muchnik ${ }^{2}$ \\ ${ }^{1}$ Institute of Economics, Geography and Demography (IEGD). Spanish National Research Council (CSIC). Madrid (Spain). \\ e-mail: javier.sanz@cchs.csic.es (corresponding author). \\ ${ }^{2}$ Until 2013 French National Institute for Agricultural Research (INRA). Department of Science for Action and Development (SAD)/ UMR Innovation. Montpellier (France). \\ e-mail: josemuchnik@gmail.com
}

Submitted: 1 March 2016. Accepted: 21 March 2016

\begin{abstract}
The present paper aims to provide a critical review with respect to the literature on Local Agro-Food Systems (LAFS) in America and Europe over the last two decades, devoted to investigating the geographies of the relationships between territory and identity-based food products. In studies on LAFS, the concept of origin of food products is based upon a historical and bio-cultural analysis of food identity. Debates on territorial anchorage focus on the causal factors - natural, cultural and socio-economic - that a distinctive territory imprints on the specific attributes of identity-based foods. Moreover, the notion of geographical and organisational proximity aligns with a socio-cultural and economic approach to collective action aiming at rural development. A LAFS implies a certain spatial density and a network of mutually cooperating farms, firms and institutions, specialised in producing and marketing an identity-based food product, what can in turn be used to valorise the food identity both on the markets and also by contributing to the creation of common and public goods. A transdisciplinary view is required both for comprehending the emergence and evolution over centuries of the identity-based foods and also for understanding the role they play in constructing more sustainable rural development in the future.
\end{abstract}

KEYWORDS: identity-based foods; terroir; territorial anchorage; local governance; knowledge; local networks; America; Europe.

Citation / Cómo citar este artículo: Sanz-Cañada, Javier and Muchnik, José (2016) "Geographies of Origin and Proximity: Approaches to Local Agro-Food Systems". Culture \& History Digital Journal, 5 (1): e002. doi: http:// dx.doi.org/10.3989/chdj.2016.002.

RESUMEN: Geografias del origen y de la proximidad: Enfoques sobre los sistemas agroalimentarios locales.- El artículo tiene como objetivo efectuar una revisión crítica de la literatura aparecida en las dos últimas décadas sobre los Sistemas Agroalimentarios Locales (SIAL) en América y en Europa, que investiga la geografía de las relaciones existentes entre el territorio y los productos alimentarios identitarios. En los estudios sobre SIAL, el concepto de origen está basado en un análisis histórico y bio-cultural de la identidad de los alimentos. Los debates sobre el anclaje territorial se focalizan en los factores causales — naturales, culturales y socioeconómicos_ que un territorio distintivo incide en los atributos específicos de los alimentos identitarios. Además, la noción de proximidad organizativa lleva implícito un enfoque socio-cultural y económico de la acción colectiva para el desarrollo rural. Un SIAL implica la existencia de una cierta densidad espacial y de una red de explotaciones agrarias, empresas e instituciones que cooperan mutuamente y están especializadas en la producción y la comercialización de un alimento identitario, lo que a su vez puede servir para poner en valor la identidad alimentaria, tanto en los mercados como en el ámbito de la generación de bienes comunes y de bienes públicos. Es necesario construir una visión transdisciplinar destinada a comprender tanto la emergencia y la evolución secular de los alimentos identitarios como el papel jugado por ellos en la construcción de un desarrollo rural más sostenible cara al futuro.

PALABRAS CLAVE: alimentos identitarios; terroir; anclaje territorial; gobernanza local; conocimiento; redes locales; América; Europa.

Copyright: ( $) 2016$ CSIC. This is an open-access article distributed under the terms of the Creative Commons Attribution License (CC BY) Spain 3.0. 
"Wine, teach me how to see my own history, as if this were already ash in my memory" (Jorge Luis Borges, writer, Argentina, 1899-1986).

"More than anything, we eat symbols" (Jean Trémolières, nutritionist, France, 1913-1976).

\section{ORIGIN AND PROXIMITY IN LOCAL AGRO-FOOD SYSTEMS}

From the start of the second half of the $\mathrm{XX}^{\text {th }}$ century, Agro-Food Systems have progressively undergone substantial structural changes on a global scale deriving from the increasing globalisation of food markets. The big food and retailing enterprises have been extending their scopes of action worldwide, not only because of a generalised reduction of custom barriers, but also due to a change in the technological paradigms of foodstuffs logistics and distribution, all resulting from the adoption of innovations in information technologies. The intermediate agro-food markets, as well as the consumer markets, have increasingly acquired rates of concentration in the biggest transnational food processing and retailing firms, all as a consequence of their growing competitiveness. These large enterprises have adopted leading competitive advantages in prices and costs which, because of their dominant position, have come to prevail over the entire agro-food value chain. In particular, this affects the phases of the chain located in the rural environment, such as farmers or first-processing agro-food industries: when these stakeholders are dedicated exclusively to producing commodities, ${ }^{1}$ their commercial margins tend to be quite narrow.

As a counterweight to this globalised mass-production model, in recent times research in Social Sciences has detected emerging processes of re-territorialisation of the economy (Courlet and Pecqueur, 2013) and in particular, of agro-food systems and rural areas (Sanz-Cañada and Muchnik, 2011; Torre et al., 2013). More concretely, an alternative model to the globalised markets of agricultural commodities and mass-market food products is based on the development of alternative channels for the identitybased foods anchored in specific territories. The literature on Local Agro-food Systems (LAFS) addresses the interrelationships between identity-based foods and the territory and suggests enhancing differentiation-related strategies for local food products that valorise the quality and territorial specificity of foods. The objective of the local stakeholders involves increasing added value at local level by means of identity-based relationships between people, on one hand, and the territory they inhabit and the food they consume, on the other.

However, although standardised mass-market food products are being distributed on a heretofore unknown universal level, it is no coincidence that consumers are revealing a dual attitude and accentuating their search for identity-based references through food products. A tendency towards change is becoming consolidated in the preferences of certain segments of consumers, who are giving increasing importance to different attributes associated with the quality of food products: sensorial, environmental and those related to food safety and typicity, among others. Indeed, despite the long-lasting worldwide economic crisis, there is growing interest in local productions and in the typicity and origin of foodstuffs, especially by the middle and upper classes in the developed countries, but also by certain urban middle classes in the emerging and developing countries. Also coming to the fore within different geographic scopes is a diversity of small initiatives of short circuits and alternative networks linking producers of proximity with local consumers, based on relationships of trust, such as producer markets or consumer groups. ${ }^{2}$ Likewise, circuits of Latin American identity-based foods are acquiring a certain degree of significance in immigrant communities in North America or Europe, such as, for example, Mexican "mole poblano" (mole sauce from Puebla), the Brazilian "farinha de mandioca" (tapioca flour) or the Argentinean mate tea, among many other products.

A Local Agro-food System (LAFS), as an object of study, ${ }^{3}$ is a concentration of locally networked farms, small firms and institutions, mainly located in rural areas, which are specialised in producing and marketing identity-based food products. It involves spatial concentration of a diffused entrepreneurial and institutional mesh of agricultural farms, agro-food industries, marketing companies, auxiliary industries and service enterprises to farmers and food firms, sectoral institutions and local development agencies, all located in one single territory and presenting a relatively high degree of spatial specialisation of production.

The LAFS is not only a specific object of research, but rather constitutes a conceptual approach for analysing the development of food local resources. The literature on LAFS critically explores a variety of agro-food proposals featuring the production of unique local identity-based foods linked to specific territories. This approach is not only a supply-oriented one: it also focuses on the relationships between producers and local consumers. In research on LAFS, territory constitutes a central analytical category, considered as an inter-linked combination of local resources -environmental, agricultural, technical, juridical, regulatory, human, social and economic ones-, all responsible for the identity of the product, and can be used for obtaining differentiation-related revenues linked to the territorial specificity of the food product. Focal points of the research involve an analysis of the identities ascribed to food, the patrimonialisation processes and the value-adding strategies of the LAFS at local level, which may or may not imply development of labels of quality. LAFS scholars have achieved significant institutional advances in the Franco-Mediterranean scope through regulation of food products with certification labels linked to specific territories - this is the case of geographical indications (GIs) - , which are becoming increasingly disseminated in recent times in other European areas and worldwide.

Research on LAFS makes use of concepts and methodologies influenced by varied and complementary sources of scientific heritage: cultural, historical, social, 
environmental and agricultural analyses are integrated into geographical and economic research on local identity-based foods. First, Rural Anthropology has provided the concepts of food identity, food heritage, symbolic capital and patrimonialisation, among others. Second, LAFS studies incorporate, as a basic requirement, the investigation of historic processes defining both the creation of local food identities and the governance of local communities. Third, Agro-food Economics has contributed to LAFS studies by means of, among others, the theories of "Distinctive Signs of Quality", which investigate the differentiation-related strategies adopted by farms, firms and institutions regarding local food products, as well as the consumer preferences concerning the attributes of origin and quality of foods. Fourth, the Regional Social Sciences ${ }^{4}$ address the benefits for territorial development of the spatial concentration of firms specialised in an economic sector, anchored within a specific territory: in LAFS studies, the theoretical concepts of spatial density and proximity are inherited from the theories of "Local Production Systems" and the literature on "Marshallian Industrial Districts". 5

The general objective of the present paper is to provide a critical and reflexive review with respect to LAFS scholars, focusing on analysis of the relationships between identity-based foods and their specific territories in America and Europe. ${ }^{6}$ We aim to address two core specific objectives involving investigation on the relationships between territories and identity-based food products. First, debates on territorial anchorage focus on the analysis of origin, or the causal factors inherent to spatial diversity that a specific territory imprints on the typicity of identity-based foods. A core question in research on LAFS, referring to the concept of origin, involves understanding how the natural, cultural and social heritage factors anchoring a food to a specific territory can differentiate these identity-based products. To this end, there is a need to investigate the historical dynamics involved in constructing the identity of local foods, through recognition of the inter-relationships developed among the different categories of specific heritage resources determining a great diversity of LAFS.

The second specific objective of the paper involves analysing the effects of the proximity of farms, firms and institutions, inherent to the activity of LAFS and based on collective action, on the development of local networks - knowledge, trust, supplier-costumer, etc.- among local stakeholders and on rural and territorial development. A second research question addresses the issue of whether and how local stakeholders can valorise the food identity and the territorial specificity by means of local proximity, not only commercially on the markets, but also by contributing to the generation of common and public goods - for instance, conservation of agro-ecosystems, landscapes and bio-cultural heritage, maintenance of the population in rural areas, or creation of networks of knowledge, among others.

Next, an initial Section is devoted to analysing the categories of anchorage factors determining the diversity of LAFS and the territorial identity of foods, as well as the role they play in contributing to generating the differential attributes of the identity-based products. A second Section argues that processes of territorial anchorage are a consequence of historical processes that evolve in time and space at different speeds. The debate on the processes of construction and evolution of the food identities, known in the literature as the patrimonialisation process, is addressed in a third Section. In a fourth Section, we will debate upon the way in which a LAFS, implying a certain spatial density of mutually cooperating farms and firms producing an identity-based food product, can generate territorial benefits in rural development.

\section{TERRITORIAL ANCHORAGE FACTORS OF IDENTITY-BASED FOODS}

The dynamics of anchorage of food products result from the activation of an inter-linked combination of local resources - environmental, agricultural, technical, juridical, regulatory, human, social, and economic oneswhich are responsible for the identity of the product and can be used to obtain differentiation-related incomes linked to the territorial specificity of the food product. The degree of territorial anchorage of the LAFS increases with the intensity of the links between identity-based foods and specific territories.

With the concept of "terroir,"7 French Agro-food Economics has contributed to the analysis of anchorage of foods. Terroir, widely known when applied to the designations of origin of wine, refers to the territory in which a typical food originates. It can be defined as a bio-social construction, or a process of bringing together the agrarian biodiversity, practices, techniques, know-how, networks of economic stakeholders and institutions around the local production of a typical food product (Casabianca et al., 2005; Deffontaines, 2005). Terroir is a relevant analytical tool for interpreting quality organisation issues in the territory. A terroir product is also rendered as a consumer segment or niche, a quality attribute for which consumers are willing to pay a premium price.

LAFS scholars have identified three categories of anchorage factors, or causal factors of the local food identity, as heritage elements constructing the territory of agro-food specificity: those relating to natural heritage, those referring to cultural heritage, and thirdly, the socioeconomic and institutional networks.

Firstly, the source of variability of natural heritage arises from the physical environment and landscapes, the physical-chemical characteristics and structure of soils, the climate - seasonal temperatures, pluviometry, humidity, winds, etc.- , the ecosystems and the biodiversity in an area. For instance, quality and type of soils significantly influence the typicity of wines, whereas pasture composition is a key factor for the gustative qualities of meat and dairy products. Biodiversity also includes the local bacterial ecosystem, which is a key element in defining the typicity in many foodstuffs produced by means of fermentation, which is particularly relevant for chees- 
es. Biodiversity is conceived herein as the diversity of living beings and their genetic heritage, resulting from their evolution over time in different ecological systems subjected to an increasing anthropogenic impact.

Nonetheless, the biodiversity inherent in LAFS is not only bio-physical but bio-cultural in nature, because it is a consequence of historical processes that incorporate a range of specific knowledge, traditions, tastes, skills, techniques, know-how and symbolic values constructing the agro-food cultural heritage of a territory. The ties between natural and cultural heritage are expressed within LAFS scholarship through the concept of bio-cultural diversity, which arises from the co-evolution of plants, animals and people connected through a culture of techniques and know-how embedded in agronomic and agro-industrial practices employed to produce identitybased foods (Bérard and Marchenay, 2004). Animal breeds, plant varieties and cultural landscapes correspond to an accumulation of knowledge, know-how and practices over time. As a consequence, the loss of an identitybased food involves a loss of bio-cultural diversity. Sometimes, in the case of rare native varieties or animal breeds, it can also entail a loss of genetic resources.

Thirdly, food typicity — or, more broadly, food territorial specificity - depends upon the establishment of agrofood bio-cultural diversity within the context of specific socio-economic and institutional networks. The social construction of identity-based foods implies that such networks are responsible for the collective transmission

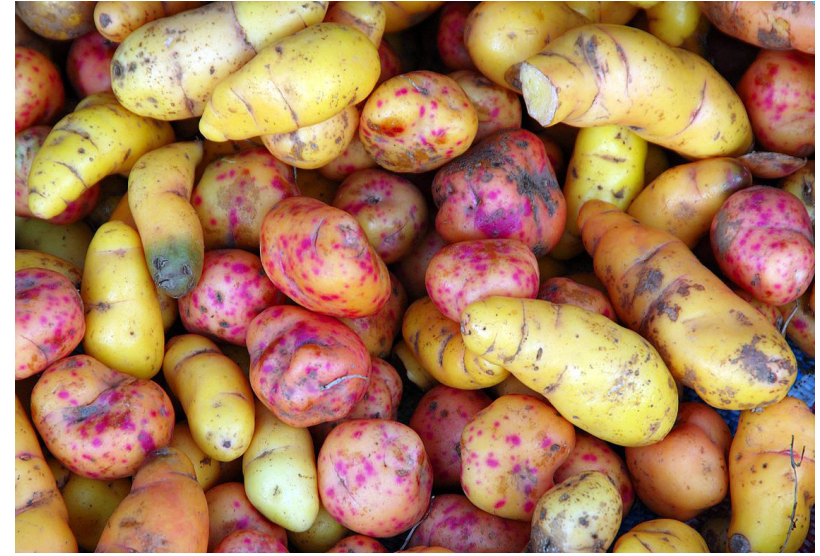

Рното 2. Ullucus tuberosus, a native species of tuber from the Andes, Southern Peru. Wikimedia Commons.

and adoption of techniques, knowledge and skills throughout time. The processes of territorial anchorage of LAFS require local stakeholders to develop collective strategies for ensuring their economic, social and institutional survival. Local institutions - Regulatory Boards of GIs, local associations of producers and consumers of organic agriculture, fair-trade NGOs, rural development groups, etc.- - are conceived as social constructs that play a relevant role in the patrimonialisation and valorisation of identity-based food products in LAFS.

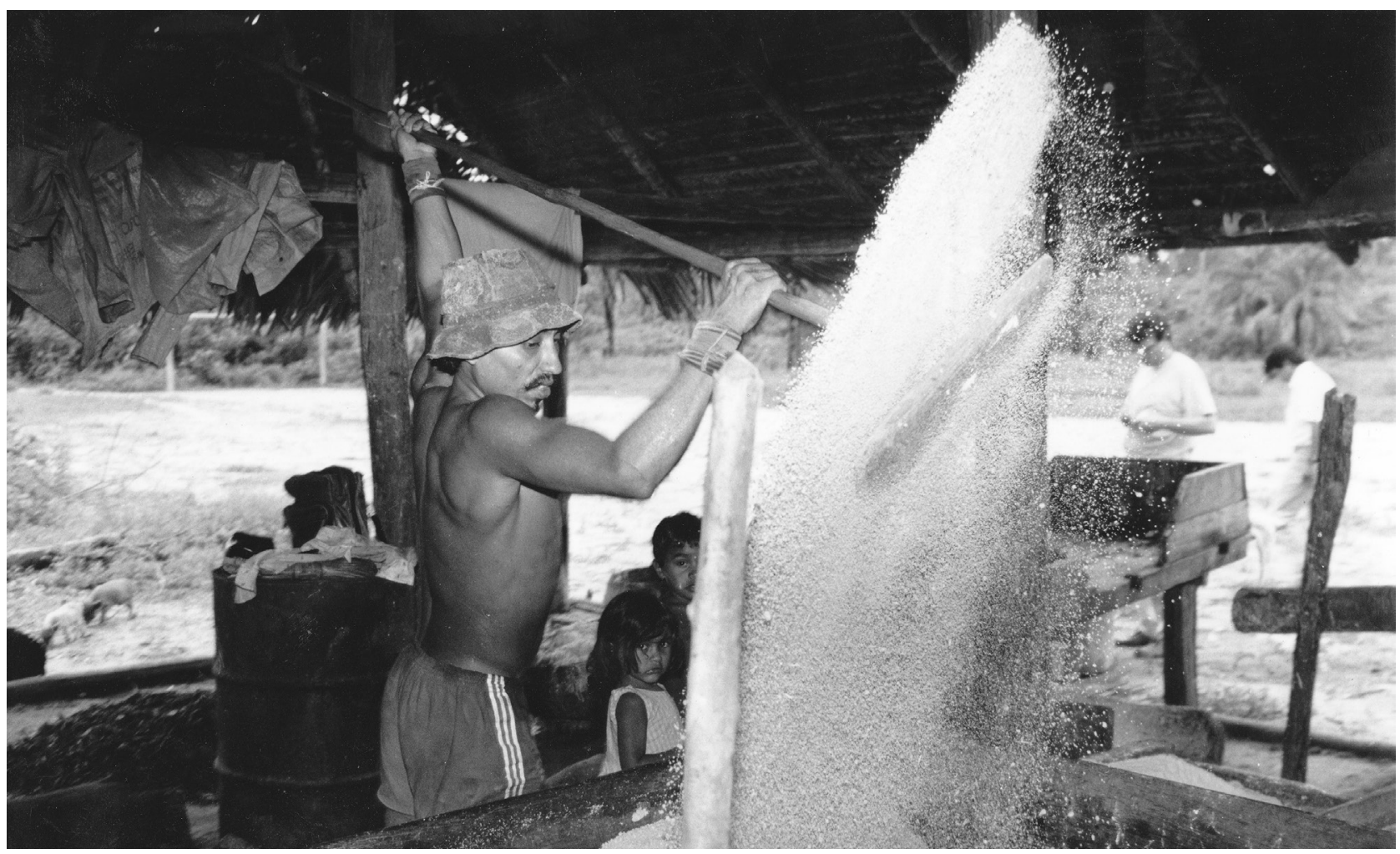

Рното 1. Artisanal skills for elaborating "farinha de mandioca" in the Brazilian Amazon. 
Some studies give priority to the cultural construction of a specific bio-physical environment, such as agricultural-heritage landscapes, which can be considered as an outstanding typology of LAFS. Guzmán-Álvarez (2016, this issue) investigates the historical evolution of the agro-forest farming ecosystems of the "dehesa" in the south-west of Spain, showing how biodiversity depends on the conservation of the cultural landscape as an integrated land-use system, with grazing as the key management factor. The dehesa constitutes a good model of how human activities can be beneficial to many components of biological diversity, and of how sustainability has been achieved throughout history: providing sufficient tree regeneration, maintaining grasslands with extensive cattle, etc. The dehesa also provides extra-quality hams and meat from the feral pigs, which have become a reference in Spanish gastronomy.

The pre-Hispanic Zapotlán saltworks is another example of heritage landscape. It is one of the few living archaeological sites to be found in Mexico, where ancient buildings of lime and stone remain, with "a mode of production dating back to ancient times, which has attracted the attention of archaeologists and ethnographers alike" (Renard, 2016, this issue). The vineyards on the traditional terraces of the Douro Valley (Portugal) and in Cinque Terre (Italy), the industrial-cultural park dedicated to meat production in Fray Bentos (Uruguay) or the cultural landscape specialised in tobacco growing and processing in The Viñales Valley (Cuba) are, among others, outstand- ing examples of agro-food cultural landscapes that are labelled as "World Heritage Sites" by UNESCO in America and Europe. ${ }^{8}$ This label represents a good opportunity not only for developing territorial valorisation strategies, but also for conservation of heritage and for provision of cultural and ecosystem services.

Moreover, the greater or lesser prevalence of different natural, cultural and socio-institutional factors in the anchorage of a specific LAFS can vary over time. An interesting example is that of the world-famous Grasse perfumes in Provence, France (Mendez and Mercier, 2005). Production began in the XVI ${ }^{\text {th }}$ century, when flower cultivation was developed in the city and in the surrounding areas to attenuate bad smells coming from the tanneries. This was the beginning of a long tradition of perfumery in Grasse, where essences were initially obtained from locally produced flowers. Four centuries later, although the perfumes are mainly based on synthetic fragrances, Grasse perfumes' carefully protected know-how, identity and territorial image have all maintained and improved the reputation and the economic dynamism of this LAFS (Fourcade et al., 2010). Territorially embedded cultural and socio-institutional factors are currently the principal reason for the strong anchorage of this LAFS, which is also the result of a continuous promotional strategy over time of both the identity-based perfumes and of the territory of Grasse.

The literature on LAFS reflects other cases in which anchorage factors deriving from the natural environment

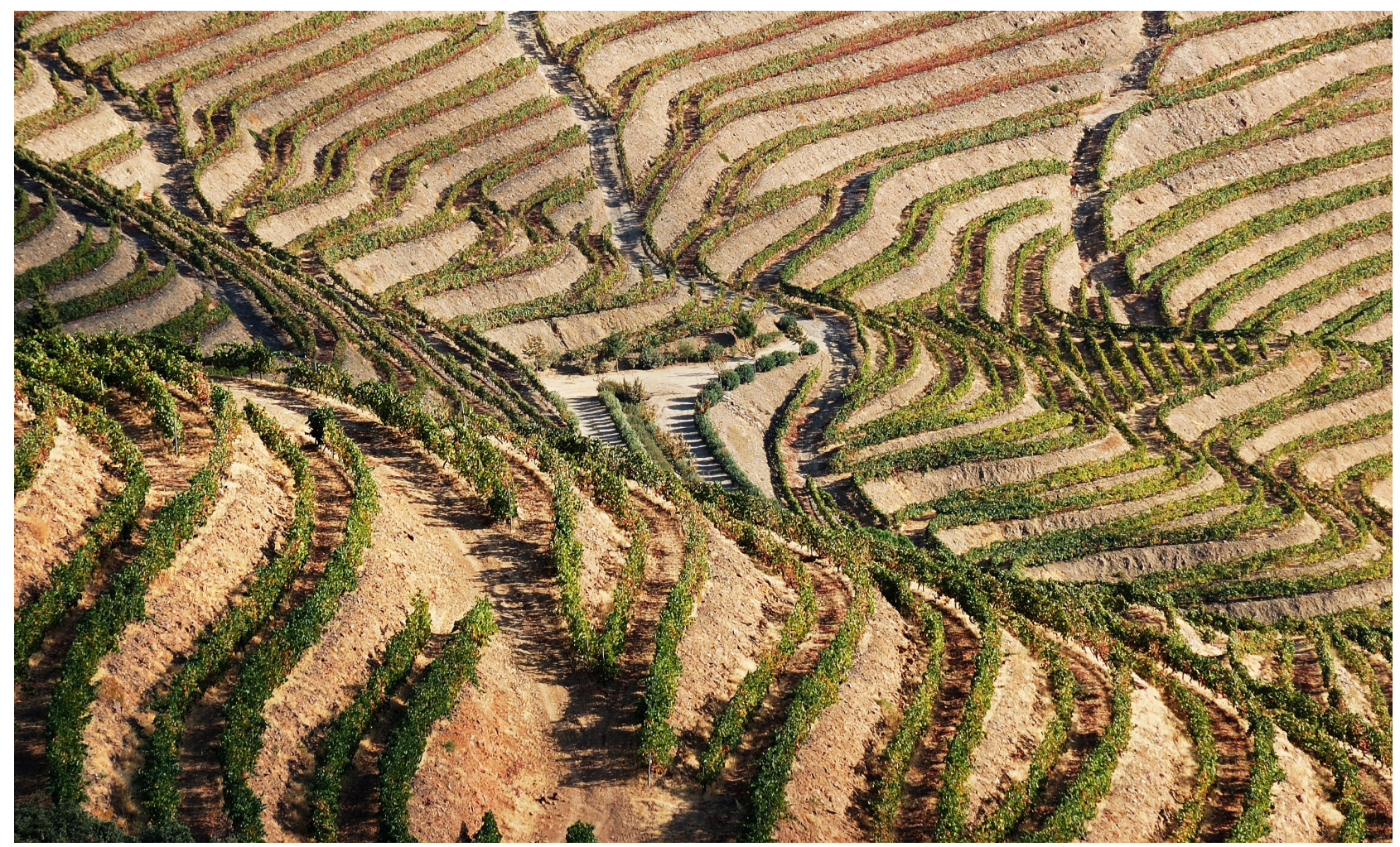

Рното 3. Bio-cultural landscape of terraced vineyards: World Heritage Site of the Douro Valley, Portugal. Wikimedia Commons. 
are giving way to other factors of a cultural nature, which have become the elements exclusively responsible for LAFS' current foothold. Garufi-Aglamisis (2014) studied the territorial reputation of an identity-based food product, the "Castilleja de la Cuesta" oil pastry, which involves unique characteristics, gastronomic excellence, technical know-how and the capacity for intergenerational transmission. Territorial reputation constitutes the principal cause of LAFS' current success on the outskirts of the city of Seville, while the production of the raw materials - mainly flour and olive oil- has partly lost its locational attraction: they are no longer locally produced.

\section{TIME AND SPACE IN THE ANCHORAGE OF FOODS}

A conceptual point of departure in LAFS studies is therefore based on the idea that territorial anchorage of food production results from historical processes which have evolved over time, often during many centuries, and at different speeds. The debate on the territorial anchorage of foods focuses not only on the characterization of the food identity, but also on the dynamics of identifica- tion. Construction and transformation of a food identity involve foods, consumers, know-how, trades, landscapes, images and a feeling of belonging to a place. Moreover, these processes are based upon exchanges among different cultures. Local societies enhance the anchorage of an identity-based food throughout history by means of collective networks and inter-generational transmission of specific knowledge, know-how and skills. On the contrary, depopulation, local conflicts or the intense competitive pressure of mass-markets can also contribute to the deanchorage of a typical food product.

Furthermore, identity-based foods do not only evolve over time, but also in space, travelling from one continent to another. For this reason, the concept of territorial anchorage can be considered, in our opinion, as a metaphor to describe the continuing journey of humans, products and skills. Many of the currently most famous typical food products in the world, such as meat from the Argentinean "pampas", Bordeaux wines, olive oil from Andalusia or Italian pasta, once historically arrived at their present places of production, as people created, adapted and disseminated skills and technology over time to anchor such products elsewhere. The arrival of the potato to

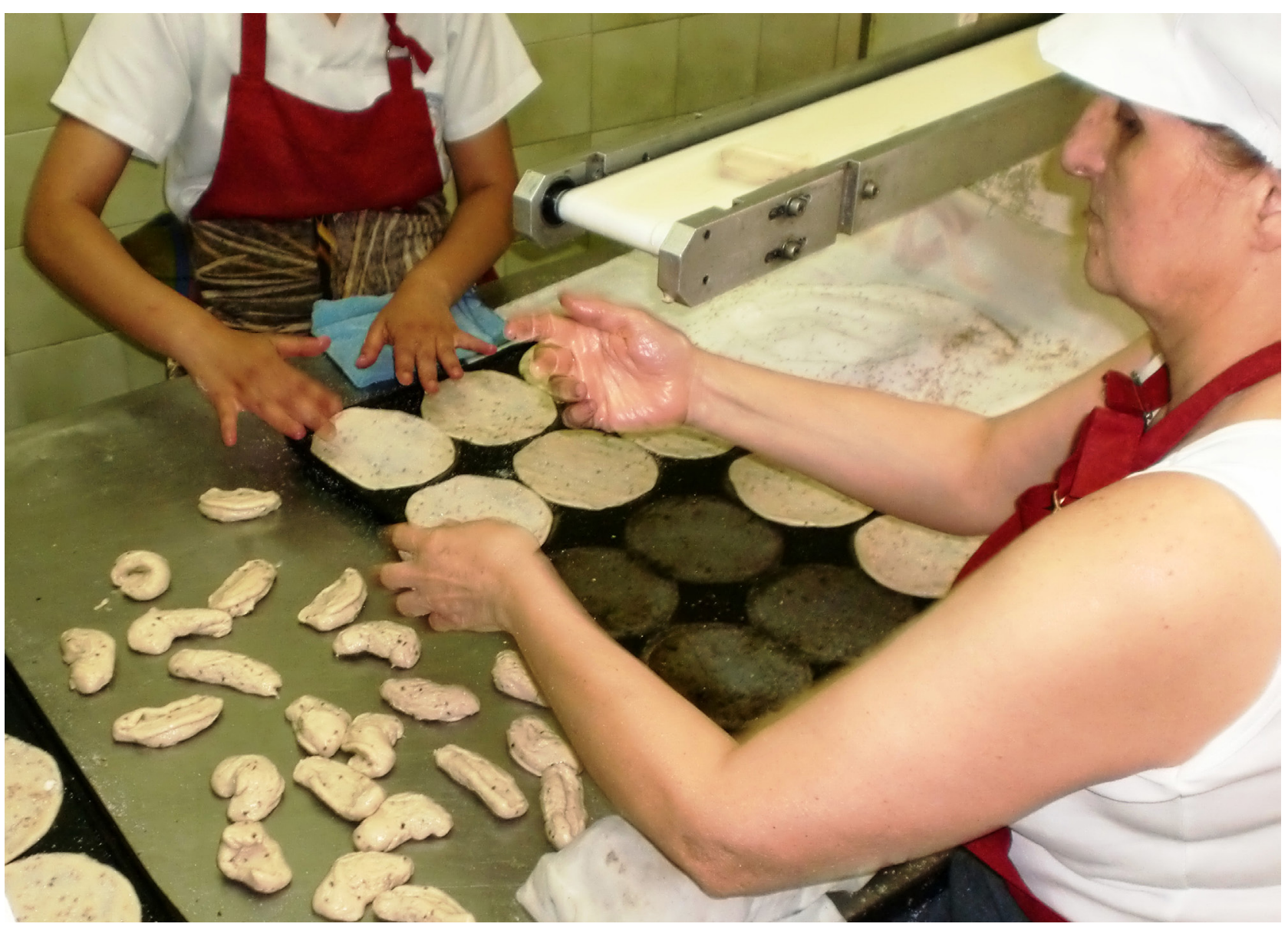

Рното 4. Artisanal skills for elaborating "Castilleja de la Cuesta" oil pastry, near Seville, Spain. Acknowledgements to Jorge Garufi-Aglamisis. 
Spain in the $\mathrm{XVI}^{\text {th }}$ century, along with its gradual dissemination throughout Europe in the XVIII ${ }^{\text {th }}$ century, promoted the creation of new gastronomic identities. This is also the case of many other products from America, such as tomatoes or beans, which gradually became an essential component of many traditional European dishes. Products from Europe, such as beef and lamb, in time became an integral part of numerous local American gastronomies as well. For instance, currently renowned European GIs, such as the "Pomodoro San Marzano" (tomato) in Campania, Italy, or the "Faba" (bean) from Asturias, Spain, both developed native autochthonous varieties only after the $\mathrm{XVI}^{\text {th }}$ century, when these cultures came to Europe from America; however, both products currently occupy a privileged place in the gastronomic identity of Italy and Asturias, respectively.

This transit of food throughout history has given rise to substantial changes in the diet and the preferences of the societies receiving these food products and has therefore created new culturally hybrid food typicities. The salons, restaurants and bakeries in Europe at the end of the XVIII $^{\text {th }}$ century were places where the urban vanguard elite could adopt new food products, for instance coffee, tea, chocolate and many other foodstuffs. Subsequently, consumption slowly but surely spread to broader segments of Europe's population, and later to other parts of the world (Scholliers, 2009).

Additionally, these processes of territorial anchorage of food products have taken place throughout history at different speeds. Numerous identity-based foods have undergone millenary processes of anchorage, as is the case of wine and olive oil in the Mediterranean Basin, or prickly pear or maize in Mexico, or of so many other food products from different continents. The case of Roquefort cheese is illustrative of a product that is deeply rooted in the terroir: it is the world's oldest non-wine PDO, dating back to 1925. This firm anchorage is due to a series of factors, among which Frayssignes (2001) highlights a process of collective learning oriented towards the creation of local resources. Collective actions by the local inter-professional organisation ${ }^{9}$ and by the livestock farmers' organisations, consisting of establishing a set of formal and informal rules of functioning and of activities aimed at diversifying the cheese-based tourism, have served to counteract the factors of instability promoting the standardisation of the product, such as a high level of overproduction of milk at certain moments of its history. Among these factors, we also highlight the fact that the stakeholders are highly heterogeneous and present very different interests: around two thirds of the economic value generated by the PDO corresponds to a multinational company, Lactalis, working alongside small handicraft companies operating from caves and one co-op.

At the other end of the scale with regard to anchorage speed, new LAFS were created at the start of the 2000s: the "Associations de Maintien de l'Agriculture Paysanne" (AMAP) in France, which were dedicated to periurban farming of ecological fruits and vegetables. The AMAPs

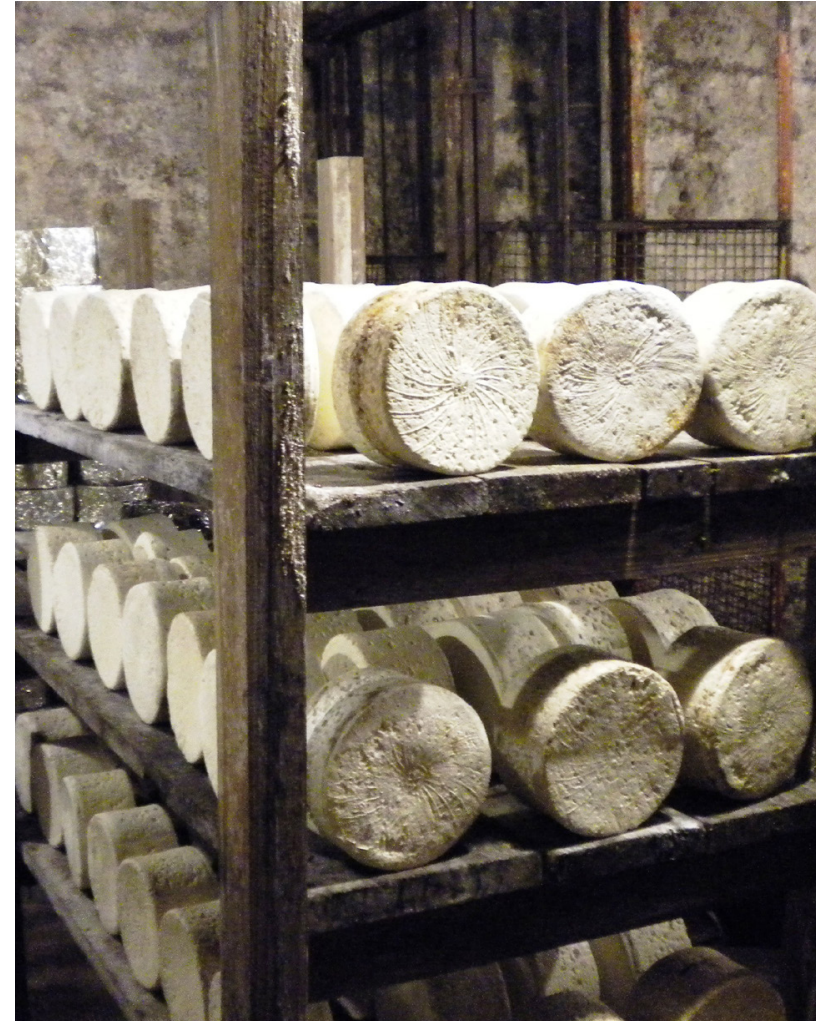

Рното 5. Cheese ripening in a Roquefort PDO cave, Aveyron, France. Wikimedia Commons.

are consumer groups ${ }^{10}$ that generate new agreements and relationships with periurban organic famers operating on proximity supply chains, guaranteeing them temporal stability in the contractual relationship, as well as fair prices. Although consumer groups do not necessarily call for the involvement of identity-based foods, this does occur in the case of France's AMAP and particularly in the region of Provence, where the model first arose. The AMAPs are becoming firmly anchored in the territory in a relatively short time from the historical point of view, for several reasons (Minvielle et al., 2011). First, the diversity of the fruit and vegetable products to be included in the basket, particularly when concerning rare and autochthonous varieties, is highly valued by consumers. Additionally, the AMAPs are an identity-based entity whose core ideas involve the search for tastes lost in childhood, as well as other symbolic values. Likewise, there exists a significant concentration of AMAPs on the outskirts of Marseille, which enables intense relations between producers and consumers, as well as the creation of synergies of territorial development.

These emerging processes of localisation might have also been generated by LAFS anchored in nearby areas. Torres-Salcido et al. (2016, this issue) analyse the rapid establishment over the last few decades of a prickly pear cactus ("nopal") LAFS in Tlanepantla, Mexico, promoted by the socio-institutional networks of a LAFS that had been historically anchored in a neighbouring area (Milpa 
Alta). The fact that the prickly pear has a high symbolic value for the peasant workers in Central Mexico, the suitable characteristics of the natural environment, and a lack of agricultural alternatives presenting a reasonable degree of profitability, have all contributed to this process of territorial extension.

Another example of an emerging LAFS, although not consolidated, is that of "local foods" in some states of the USA, which is especially innovative because it is occurring in an Anglo Saxon country whose food production and consumption have not traditionally involved identitybased foods. Trubek (2008: 93-138) conducted an ethnographic analysis addressing how the concept of terroir is starting to be incorporated within certain culinary scopes by California's top chefs. An attempt can be seen to create a new food identity by the renowned gourmets and cooks, whose proposals involve consumption, the restaurant business and identity-based food producers and manufacturers.

However, the anchorage of a LAFS to its territory is not necessarily permanent. In this sense, the literature also contains cases of de-anchorage processes of food products that had once been well anchored in the territory. The example of de-anchorage of chocolate production is quite revealing. Given its symbolic and economic value - "Theobroma cacao" means "food of the gods"-, chocolate was reserved mainly for Maya and Aztec priests, warriors and families of high social class, as well as for other pre-Hispanic cultures in Mexico. Chocolate was used in religious ceremonies or in weddings among the nobility. When the colonisers learned how to prepare it and brought it to the Spanish Court in the $\mathrm{XVI}^{\text {th }}$ century, it became a product that was long reserved for European nobility, who made certain changes to adapt it to their taste (Beyer, 2011). ${ }^{11}$ In the XIX ${ }^{\text {th }}$ century, chocolate became industrialised and the most reputed chocolate is nowadays made in Switzerland and Belgium, where cocoa plants cannot be grown. The big multinational chocolate companies, like Nestlé, currently use mixtures of cocoa from different places and are opposed to using the label "origin" in their marketing strategies. This means that despite the fact that chocolate was well anchored culturally and symbolically in Mexico's pre-Hispanic cultures, today it is marketed as a product that is completely separate from the attributes of its production.

Elverdín et al. (2011) analyse the case of an activity that had traditionally been anchored in the territory: the extensive beef production systems on the "Pampa" of Argentina, which rapidly started to become partially de-anchored half-way through the 2000 s, due to a global process involving a rise in soy prices. This crop quickly came to represent an alternative land use, contrasting with beef production on the Pampa. Although this tendency reverted in 2012, the increases and decreases in the prices of raw materials, such as soy, as a consequence of their nature as commodities subjected to speculative pressures from the global markets, can endanger the sustainability and territorial equilibrium of the LAFS.

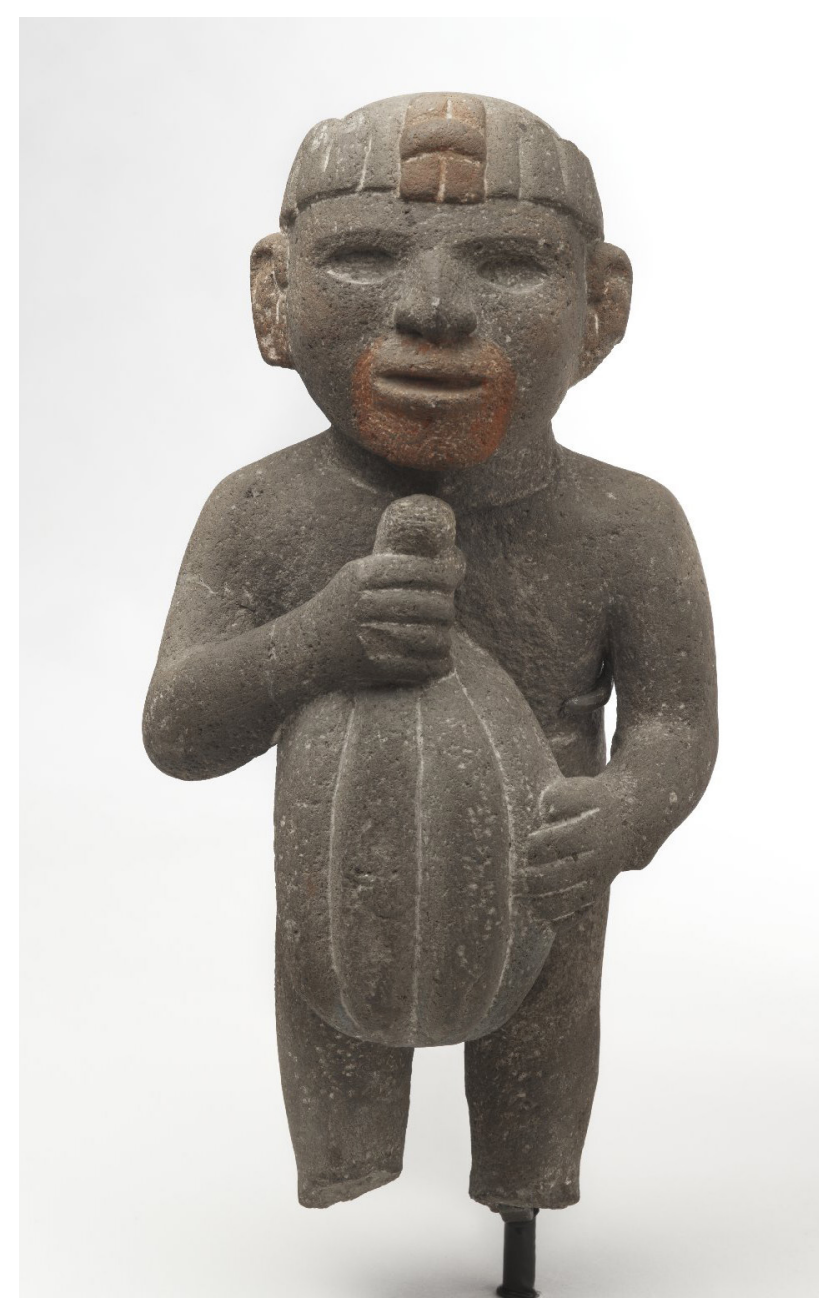

Рното 6. Aztec man carrying a cacao pod (1,440-1,521). Brooklyn Museum, New York. Wikimedia Commons.

As an element of resistance to LAFS delocalisation, processes of patrimonialisation of identity-based food products constitute the first step in local agro-food development strategies, particularly in the case of products that have recently undergone phenomena of standardisation of production and mass consumption. Praly et al. (2007) examine the collective territorial development strategies of the arboriculture LAFS in the Rhone Mid Valley, France. In a context of intense liberalisation of fruit and vegetable markets worldwide, local arboriculture has undertaken a strategy to combat processes of delocalisation towards other Mediterranean countries offering cheaper labour: this phenomenon has affected numerous production areas in France. This strategy is based upon the following axes: promoting specific quality, with emphasis on native varieties; respect for the environment and for the values associated with heritage and landscape; maturation of the tree; products destined for local consumers. The literature reflects other examples of processes of de-commodification based on promoting the establishment of GIs in products presenting a strong identity and history, but which 
are still predominantly marketed worldwide as commodities and sold as standardised products: the coffee GIs in Central and South America (Marescotti and Belletti, 2016, this issue) or the olive oil PDOs in Spain (SanzCañada, 2009).

\section{PATRIMONIALISATION OF LOCAL FOODS}

Historical links to origin and identity-based references, through the common feeling of belonging to the history of a place, all constitute the basis of affection for the emergence of empowerment and projects of local stakeholders. Patrimonialisation of a food product is a historical-cultural process of construction of common identity-based references at the local scale, the purpose of which is to confer upon these food products greater symbolic significance and cultural density. This process first involves a previous phase of identification of the food specificity, referring to the practices through which local populations identify with typical products through acts of consumption and production. The patrimonialisation path also engages at least the following main phases: i) coding the differential quality of the product linked to the origin, to be specified tacitly or by establishing collective brands involving distinctive signs of quality; ii) historical construction of the identity of the food product, which calls for promotion and communication strategies of this identity throughout time, as well as for an empowerment of the food identity by the local population.

Coding the differential quality of the product linked to the origin involves spatial identification of the terroir, as well as the technical characteristics and production practices providing a threshold of differential quality in a specific identity-based food product. These dynamics present a technical aspect in which a definition is provided, among other things, of varieties or animal breeds, practices, know-how and the physical environment determining the typicity and quality of the product. Furthermore, common immaterial goods, essential for adding value to the identity-based food products, result from the historical crystallisation of a series of practices, techniques, know-how, social relations and conventions: from an economic and cultural point of view, they should be considered as the collective symbolic capital of a LAFS (Saavedra and Macías, 2016, this issue), the value of which is higher when a product is perceived by consumers as a more territorially differentiated product.

Symbols constitute a key element in shaping the identity of food products. In many cultures, throwing away bread or rice is tacitly or explicitly considered to be taboo. Food associated with local, religious or civil festivities has a high symbolic value in many cultures, as is the case of typical Christmas food, or food used in the festival celebrating the end of Ramadan or the Jewish New Year. Moreover, numerous prohibitions relating to food are associated with religious precepts. The exorbitant prices of determined top-of-the-range wines would be hard to justify without considering their symbolic value.
A noteworthy example of the influence of symbols in food culture involves sugar cane. In Latin America, the generalised symbology associating whiteness with purity meant that in colonial times, the whiter the cane sugar, the more it cost (Muchnik, 2006). Since then, this symbolic value has had a decisive influence on the choice of production technologies: great importance has been given to the refining stage as a result of consumers' preferences, despite the nutritional advantages of brown sugar over white.

Coding the territorial quality can be seen in a tacit manner, with greater or lesser degrees of emphasis, in conventions relating to commercial transactions among local economic agents. Nonetheless, the definition of regulated quality of an identity-based food product can be explicitly materialised by means of distinctive signs of quality linked to the territory. Distinctive signs can be defined as summaries of credible information based upon visualization of a label bearing a logo, the aim of which is to enhance the product by means of reference to one or several of its differentiating attributes (Valceschini, 1999). The objective of the labels, conceived as collective brands, is to provide the consumer with some of the information associated with the sign. The most significant examples of distinctive signs linked directly to specific territories are the geographical indications (GIs). Accurate definition of quality coding of an identity-based food product, which should demonstrate a direct relationship between the specific quality of the product and the terroir, constitutes the first step in the collective regulation of a GI. The approval of these labels by the European Union (EU), as well as by many states worldwide, requires demonstrating links between the product, on one hand, and the biophysical environment, the history, the knowledge or the agricultural and agro-industrial techniques, on the other. Other types of quality signs, such as organic agriculture or environmental forest certification, are not distinguished by the territory in which they are produced but rather, they can generate territoriality by setting in motion collective actions based on the joint localisation of firms, institutions and other local stakeholders.

With regard to GIs, there is a deep-rooted tradition in Mediterranean Europe, which mainly involves protected designations of origin (PDO) and protected geographical indications (PGI), ${ }^{12}$ although other types of national and regional territorial labels have been promoted. Some experiences of territorial collective labels date from the $\mathrm{XIX}^{\text {th }}$ century, such as Porto wine in Portugal. Moreover, the pioneer laws intended to protect PDOs in France and in Spain for wine production date from the 1930s. The expansion of the model of GIs on an international scale has given rise in recent times to a good number of empirical research books and articles. ${ }^{13}$

Within the processes of coding the identity of food products, the genetic heritage of native breeds and plant varieties can constitute one of the principal resources defining the typicity of the GI product. This heritage has been constructed over time through an accumulation of knowhow in genetic improvement of successive genera- 
tions. The example of charcuterie in Corsica, France, is illustrative of the importance acquired by the socio-institutional networks and by collective action with regard to defining the regulation of the PDO "Charcuterie Corse", which label was granted in 2012. Lambert-Derkimba et al. (2011) state that defining the regulations served to solve governance-related conflicts arising from the definition of racial purity and of restrictions in the feeding of pigs. On the one hand, some livestock farmers demanded a greater amount of generations of pure Corsican-breed animals for reproduction to inscribe an animal in the PDO, calling for exclusively natural feed based on chestnuts and acorns; on the other, there were breeders who wanted the regulations to establish a lower number of generations and the possibility to complement some of the pig feed with barley.

Depending upon their historical tradition and degree of collective organisation, GIs enjoy very different degrees of reputation. We could quote a whole range of well-known success stories, such as Champagne, Bordeaux wines or Roquefort, Parmigiano Reggiano and Feta cheeses. These PDOs, on the basis of identity and knowledge, globalised their territory in marketing terms, projecting these products worldwide, while simultaneously protecting them legally from possible unfair competition. The most widespread and consolidated model, with the longest historical and organisational tradition, involves nowadays the wine sector: consumers currently demand a certified label as a guarantee of a determined level of quality. Over $57 \%$ of the 3360 GIs existing at the start of 2106 in the EU involve wine production. ${ }^{14}$ Spirits, fruits and vegetables, cheeses, oils, fresh meats and transformed meat products are other widespread products within the model of GIs in the EU.

In the last few decades, other countries in the Centre, the North and the East of the EU have also enhanced this kind of labels. More recently, a large number of countries from America (Canada, Mexico, Argentina, Brazil, etc.), Asia (China, Vietnam, Japan, etc.) and Africa (Morocco, Tunisia, Cameroon, etc.) have developed national laws on GIs, inspired by EU regulations. Highly reputed identitybased food products from different continents have obtained GI assignation, such as Argan oil in Morocco, Tequila in Mexico, Pisco in Peru, Rooibos tea in South Africa and Pinguu peach in China, to mention just a few very significant examples.

Processes involving construction of food heritage are emerging at national or regional level in countries in which legislation on GIs has recently been established and the model has not yet become consolidated. A significant example is that of Quebec, Canada. Since the start of the XXI ${ }^{\text {th }}$ century, terroir food products have emerged and achieved repute, promoted by territorial development policies: the creation of agro-tourism routes, festivals and museums, proximity markets, terroir retailer brands, etc. In 2009, the first Quebec PGI was obtained, Charlevoix lamb. Chazoule and Lambert (2011) analyse the policies intended for the creation of identity-based food products, which for consumers must focus upon promoting and valuing attributes relating rather to "proximity of food production processes" and "maintenance of the peasant economy" than to the concept of "typicity", which is not so deeply rooted in producers or consumers in North America, in comparison with other world areas such as the Mediterranean or Latin America.

Additionally, the patrimonialisation process must also involve a specific strategy of promotion and communication throughout time at local scale, which incorporates signs of identity in food products that are easily recognised by consumers: landscape, historical and cultural features, specific techniques, etc. Museums, festivities, festivals, markets and campaigns are, among other activities, relevant tools for enhancing the patrimonialisation of local foods. Relationships between territorial identity and quality of food products currently reach a high level of relevance and complexity in local societies. Adding value strategies usually involve an "aggiornamento" of these traditions to the demographic, economic, technical and above all, gastronomic changes currently taking place. Modifying the animal-fat content or the appearance of a food product, or inventing new recipes in order to incorporate a food product into the new culinary tendencies, doubtlessly constitute ways of valorising territorial food cultures. For traditions to persist, they must be in constant evolution.

Processes of patrimonialisation of food products can even become the basis for construction of the general identity of a region or of a nation. A significant case involves Italy, which in medieval times fundamentally comprised a network of cities, which were autonomous and self-governed by the political and religious powersthat-be. Since the end of the Middle Ages and during the Modern Age, citizen estates extended their rule to the surrounding rural territories: therein, the countryside produced the food, which was concentrated and marketed in the city. For centuries, the identity of food products in Italian cities was really a local one, which did not permeate much from one territory to another. However, in 1861, in times of the Italian unification, the need to construct a national identity arose in great measure from a common food identity, in which great appreciation for the wide range of local products became a core idea (Montanari, 2013). Emigration by millions of Italians in the last decade of the XIX ${ }^{\text {th }}$ century meant that the host societies, especially North America, defined certain common patterns of the Italian food identity. Pasta, which had theretofore been consumed mainly in the southern regions, became generalised in the Italian community living abroad, as did Parmigiano cheese, olive oil, wine and other foodstuffs. The restaurant and other foodservices business overseas also contributed to strengthening the encounter among Italian regional traditions. Likewise, many Italian soldiers who fought in the First World War came across different culinary realities, which served to disseminate the characteristics of the Italian model of food identity among the working classes.

In relation to France, Csergo (2011) reached similar conclusions. The so-called "awakening of the provinces" 


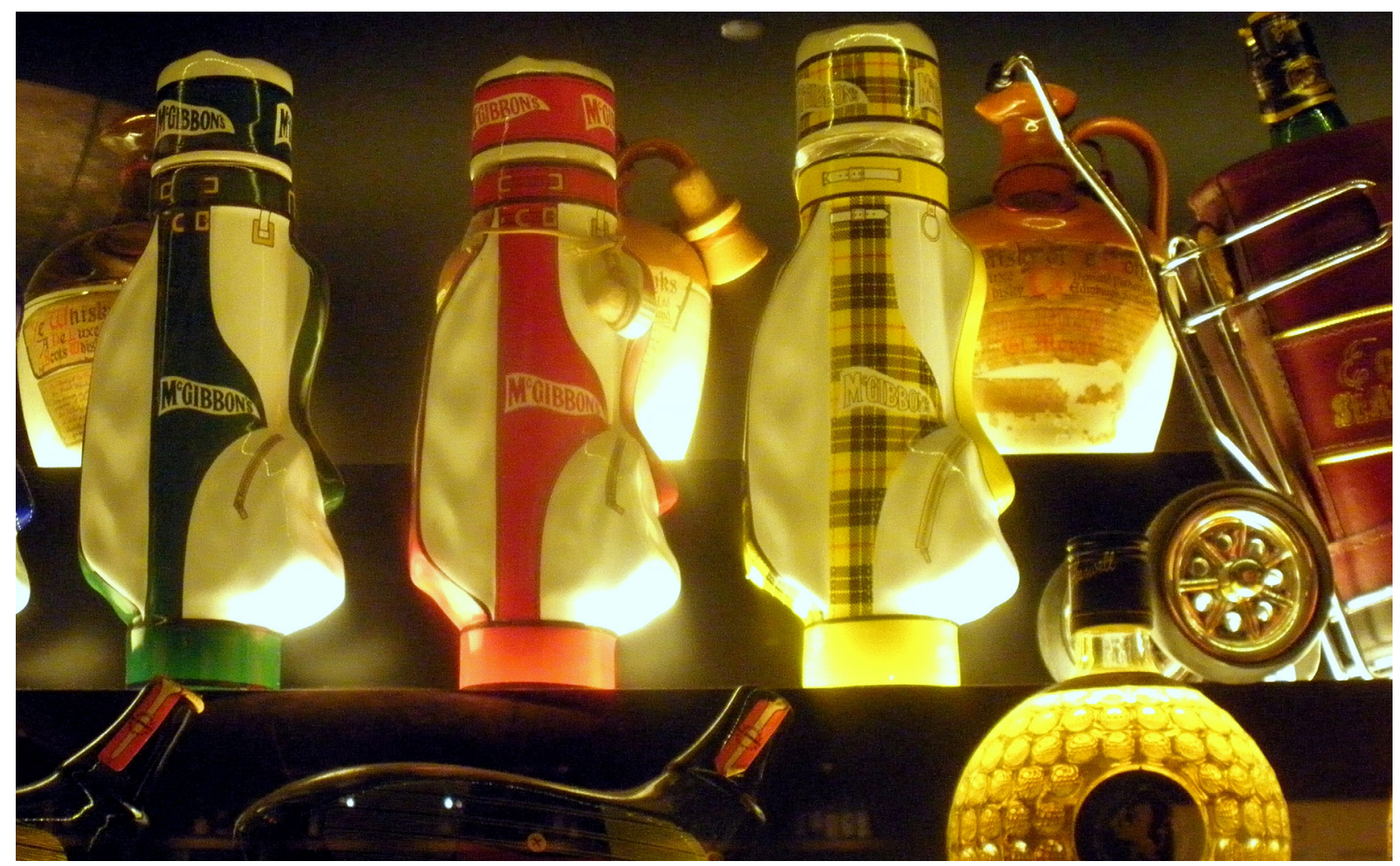

Рното 7. Patrimonialisation of local foods: Whisky Museum, Edinburgh, Scotland.

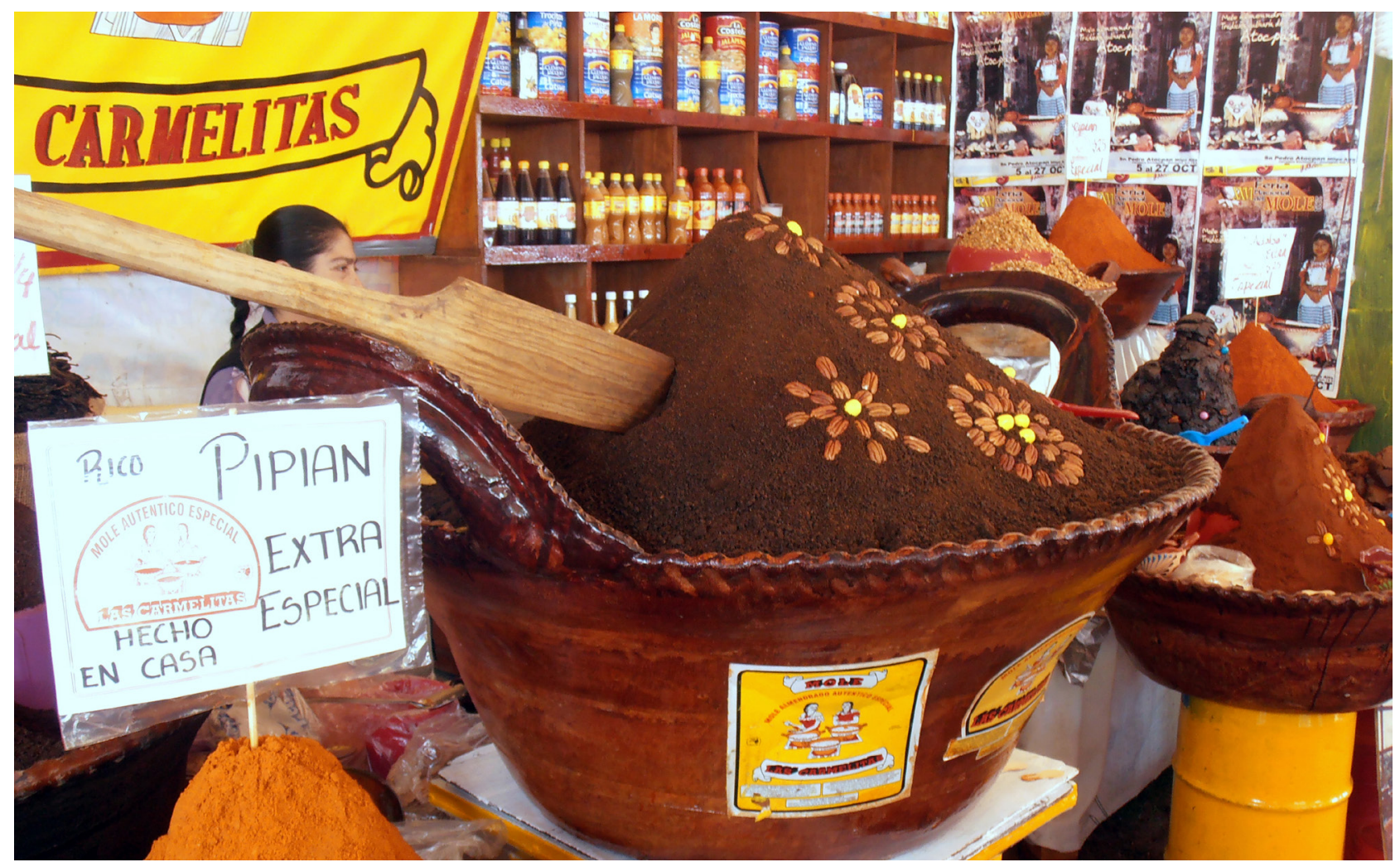

Рното 8. Patrimonialisation of local foods: National "Mole" Festival in San Pedro Actopan, near Mexico City. 
that took place during the Belle Époque converted local culinary specificities into an expression of a new national model, following a movement involving reformulation of diversities and definition of a Republican culinary identity which was initiated as from the French Revolution. As a result, the Italian or French food identities currently constitute important immaterial assets for exportation of quality food products.

\section{ORGANISATIONAL PROXIMITY AND TERRITORIAL GOVERNANCE IN LOCAL AGRO-FOOD SYSTEMS}

In the previous Sections we examined how anchorage-related factors differentiate food products, as an approach to the analysis of origin. Agrarian landscapes, microbial ecosystems, knowledge, know-how, social networks, food traditions and cultures, vegetable varieties and animal breeds are resources that can be mobilized for rural development objectives. We now debate the effects of organisational proximity on rural and territorial development, as well as the role played by territorial governance in patrimonialisation and value-adding strategies in LAFS. Local collective action constitutes a basic requirement for activating the above mentioned territorial resources for rural development.

Since the contributions of Alfred Marshall at the start of the $\mathrm{XX}^{\text {th }}$ century, Economic Geography and Spatial Economics have highlighted the effects of the spatial concentration, specialisation and proximity of firms with regard to enabling the economic and social interactions that promote territorial synergies. Italian literature, rooted in the "aggiornamento" of Marshallian Industrial Districts, which began to emerge towards the end of the 1970s (Becattini, 1979; Benko and Lipietz, 1992; Brusco, 1982), as well as French bibliography on Local Production Systems, starting in the late 1980s (Courlet, 2002; Courlet and Pecqueur, 1996), have demonstrated that spatial concentrations of specialised firms are crucial for obtaining advantages of territorial competitiveness. Proximity is particularly relevant to the economic development of small and medium enterprises located in rural areas.

Geographical proximity involves only a notion of physical distance among the stakeholders, institutions and natural factors. In this regard, French academics have drawn attention to the concept of organisational proximity, which becomes a necessary condition with regard to achieving satisfactory processes of rural development: it is defined as a social construct that determines greater or lesser proximity in the economic-organisational strategies of economic agents and local institutions (Benko and Desbiens, 2004; Rallet, 2002; Torre and Filippi, 2005). LAFS scholars have inherited this approach to geographical and organisational proximity from studies on Local Production Systems. Nonetheless, apart from the benefits of achieving greater spatial density, the territorial competitiveness of LAFS depends upon the economies of uniqueness derived from the specificities of identity-based foods and specific terroirs.

Local governance ${ }^{15}$ of agro-food activities involves partnership processes that imply networks of vertical and horizontal relationships of cooperation among stakeholders and institutions, ${ }^{16}$ the development of collective institutions devoted to ensuring quality control and organisation, and the setting-up of joint economic strategies (OECD, 2006). In order to enhance local cooperation, a specific institutional framework must be set up; herein, trust relationships and tacit rules constitute key elements for achieving social cohesion, minimising conflicts and reducing transaction costs in the commercial exchanges. A prerequisite for achieving a certain governance threshold in LAFS, which in turn is a necessary condition for successful patrimonialisation and adding-value strategies, involves the need to create a framework of territorial intelligence: a collective intelligence that transcends the sum of individual actions and is mobilised via projects and networks for innovation, training and dissemination of knowledge (Muchnik et al., 2008). Local governance can be stated at two levels: LAFS governance, which is simultaneously sectoral and territorial in nature, and territorial governance, involving the territory as a whole and, more specifically, all those agents and institutions working towards local development.

Looking upon LAFS governance, Regulatory Boards of GIs are local partnership institutions comprising farmers, cooperatives, industries, marketing companies and often public agencies. They are responsible for drawing up the reference standards of the label, registering the farmers and companies, monitoring compliance with the standards, legally protecting and promoting the label. The institutional activity of Regulatory Boards entails cooperation in the tasks inherent to the functioning of a distinctive sign. However, the effects of collective action transcend the original objective, which involves obtaining differentiation-related incomes, and a number of other positive effects beneficial to LAFS can also be enhanced. These institutions frequently adopt a series of non-mandatory tasks - apart from defining standards, certification, etc. - such as adoption and dissemination of techniques, knowledge and know-how, promotion of a local collective label, or even enhancement of local collective marketing initiatives, among other kinds of synergies at the LAFS level. Sanz-Cañada and Macías-Vázquez (2005) illustrate this kind of indirect effect when analysing the institutional network formed around the Regulatory Boards of olive-oil PDOs in Spain, concluding that LAFS institutions can create interesting local formulas both for the inter-professional organisation of identitybased foods and for enhancing rural development.

Other types of institutions can also play similar interprofessional roles in LAFS: associations of local organic producers and/or consumers (e.g., AMAP), second-degree marketing cooperatives - a cooperative bringing together local industrial cooperatives for joint marketing objectives-, fair trade local associations, non-governmental associations, rural development groups issuing 
from EU Leader programs, or Slow Food local communities, among others. Developing a local institutional framework poses a good opportunity for local farmers and artisanal enterprises, because business scale remains too small in many rural areas worldwide to individually manage activities such as training of human resources, technical assistance or marketing strategies.

In particular, we should emphasize the current expansion and spread of Slow Food, an internationally networked organisation of over 1500 local communities ("convivia") worldwide which is devoted to promoting identity-based foods and food sovereignty, as well as to preserving traditional and regional gastronomy, cultivated biodiversity and agro-food heritage. It was founded by Carlo Petrini in Italy in 1986. Slow Food has now more than 100000 members who are also integrated within a much broader network of small-scale, identity-based and sustainable production units, associations and experts on quality food, known as Terra Madre. ${ }^{17}$ Convivia organises shared meals, tastings, gastronomic festivals, visits to local producers and farms, conferences, workshops and film screenings, among other activities. Particular emphasis is placed upon education, training, dissemination and research into local foods, ranging from agricultural production to gastronomy. In 2004, the University of Gastronomic Sciences was founded by Slow Food in partnership with the Piedmont and Emilia-Romagna Italian regions: it became a pioneer in offering a holistic approach to food studies.

Another example of an institutional framework devoted to local governance, which is not based on territorial labels, is an EU-funded initiative supported by the Portuguese Leader network called "project PROVE" (Baptista et al., 2013). The project first aims to develop organisation and market access of artisanal producers of identitybased foods through proximity short chains. It also aims to encourage artisanal producers to branch into new activities, such as training, tourism and cultural activities. Local urban consumers are linked to the project, buying baskets of fresh fruits and vegetables and participating in activities organised by producers. A promotion strategy of the network based on information technologies is another focal point of the project.

Moreover, one of the most critical phases in the development of a LAFS involves the codification of the quality linked to the origin, because conflicts can arise in the decision-making processes among different local actors who present an imbalance in their degrees of bargaining power. There is a need to make essential collective decisions regarding specifications of varieties, animal breeds, techniques or codes of practices. We will subsequently refer specifically to some chief resources emerging in the literature, which can act as a lever of cooperation or conflict in shaping the governance of LAFS: innovation and knowledge, traditional techniques and symbolic capital. Additionally, other local resources articulating LAFS governance involve collective commercial strategies, training local skills or formation of social capital, among others.

First, dissemination and adoption of innovations and knowledge are perceived by many researchers to consti- tute a key source of local cooperation and development of socio-economic networks. Varying networked forms of interdependence between enterprises and institutions play a role in structuring processes of cooperation and innovation around food quality within LAFS. Cendón et al. (2014) and Chiffoleau and Touzard (2014) measure the quantity and frequency of advice relationships between managers of agro-industrial firms and other stakeholders and institutions, making use of Social Network Analysis techniques: these contributions consider the PDOs of olive oil in Andalusia, Spain, and the wine producers of the Languedoc PDO, France, respectively. Regulatory Boards and other local agro-food development institutions can assume the role of integrating poles of collective action for local stakeholders, chiefly in terms of dissemination of knowledge and innovations. Moreover, family and friendship networks, together with production networks, are dimensions that are quite inter-linked in rural areas: Crespo et al. (2014), using Social Network Analysis too, investigate the influence of social structures in determining the cooperative behaviour of cheese producers in Aculco, Mexico, in terms of the decision to adhere or not to the local cooperative.

Secondly, shared knowledge of traditional techniques, usually transmitted inter-generationally and often re-created, constitutes an outstanding resource around which local communities organise themselves ${ }^{18}$ this knowledge can be a source of cooperation or conflict among different categories of stakeholders. Bérard et al. (2016, this issue) illustrate an evocative example of how defining product specification rules for the Salers cheese PDO, France, has been a source of conflicts between two different types of stakeholders: those who required both the use of the gerle - a traditional wooden vat - and elaborating the cheese on-farm, in contrast with those opposed to the rules. Traditional agricultural knowledge regarding techniques has historically constituted the leitmotiv for building local networks of knowledge. The traditional knowledge of the artisanal cheese producers, which preserves a higher degree of typicity and natural heterogeneity of the product, clashed with the objectives of the rule-opposing group of stakeholders, which comprises bigger companies oriented towards less-differentiated markets; when using stainless steel vats, a more homogeneous product is obtained and sanitary regulations are therefore accomplished with lesser costs. Although the above mentioned rules were finally included in the product specifications, and a higher level of product typicity was protected by the PDO, governance occasionally fails, with gerle supporters and opponents at loggerheads.

Thirdly, symbolic capital represents a local aggregated capital for identity-based foods, generating a reputation that can be valorised either in the markets or through development of common goods. The collective appropriation of symbolic references for value-adding purposes becomes a major governance problem involving common immaterial goods. The example of the local food system based on cultivation of mussel seed in the Reloncaví Estuary, Chile, illustrates this debate (Saavedra and Macías, 2016, this is- 
sue). Symbolic capital depends foremost on two associated reputation attributes: the "identity of ecologically pristine waters", where the mussel-farming is based, and the "traditional culture" of seashore cultivation - collection with the use of old nets - , which has a positive impact on the quality of the seeds. Failure in territorial governance of the LAFS prevents the local communities from adding sufficient value. Artisanal fishermen, farming associations and some small local and national fattening micro-businesses can hardly valorise the local symbolic capital, due to their poor bargaining power in relation to the marketing and export companies and to some big mussel collection and fattening firms. The latter concentrate most of the local valorisation for commodified and mass-market production, expropriating the local collective symbolic capital, which belongs to the whole local community.

Additionally, the economic and institutional activity of a LAFS may not only have positive effects on governance of the LAFS itself, but also on territorial governance as a whole. Studies on LAFS show that setting up local agro-food development institutions can contribute to generating collective benefits for the whole territory they belong to by means of the inter-institutional relations they encourage. These collective benefits are called externalities, which in Economics mean the indirect benefits or costs affecting third parties who do not incur in an economic transaction. For instance, the beneficial effects of conserving a genetic heritage, a typical cultural tradition or an agricultural landscape do not concern only the members of a LAFS, but also the local society as a whole. Studies on LAFS provide a good number of illustrations of successful rural development experiences based on local value-added strategies of identity-based foods which promote positive territorial externalities - socioeconomic, cultural, environmental, technological, etc.- - , or which reduce negative ones mainly those of an environmental nature.

First of all, as a general issue, LAFS activity can represent a lever of empowerment and social debate in local development dynamics, stimulating not only networking and cooperation among LAFS stakeholders and institutions, but concerning other local economic sectors and civil society too (Belletti and Marescotti, 2011). Well-rooted LAFS can also contribute to disseminating and promoting a general local culture of quality, encouraging quality in other food or artisanal products, as usually occurs in regions with a good general reputation for identity-based quality foods, such as Tuscany in Italy or Provence in France.

Enhancement of economic concentric diversification activities, together with the building of a positive reputation of a region can become relevant positive territorial externalities created by the development of LAFS. For enhancing reputation, it is recommended to jointly obtain promotional synergies both from the typical product and from its specific territory. Moreover, territorially based institutional arrangements between different agro-food and non-agro-food producers bring together different rural activities, including tourism, culture, food, gastronomy and recreation: they can generate benefits not only in the agro- food sector itself, but also in the local tourism and services sectors. In this sense, the literature refers to the contribution of local productive systems to the production of a territorialized basket of goods, or a composite supply of different products and services linked both culturally and naturally to a specific territory (Pecqueur, 2001). Wine routes, cheese routes, olive oil routes or salt routes, are strategies born in Mediterranean Europe that are now spreading throughout other geographical areas of the world. The enhancement of local gastronomic heritage can also constitute the central argument for developing diversified activities from farmer to table: Trubek (2008) analyses nonprofits partnerships between farmers, chefs and culinary institutions for building a new symbolic capital that had barely existed before in some states of the USA (California, New England, etc.). Finally, formation of human capital and building social capital in new economic activities are other relevant externalities that respond to a broader territorial development objective.

An interesting case of concentric diversification and creation of an image of product and territory involving a strong symbolic component is that of Guérande salt, in Brittany, France. The reactivation of the salterns in the 1970s by means of setting up a co-operative was considered to constitute an exemplary experience for heritage conservation and valorisation. A technical training programme was created which was especially devoted to transmitting commercial knowhow. A PDO and other quality labels were established. Both the range of salts on sale ("fleur de sel", etc.) and the range of products including salt as a component were differentiated (bath salts, charcuterie, mustard, etc.). Synergies were created for promotion and consumption of food production and tourism activities. The articulating element of the territorial development strategy, which united enterprises, associations and local institutions, as well as other local sectors, lay in the image of the territory, around which local development alliances and initiatives were established (Fourcade et al., 2010). The slogan of the territorial development strategy sums up well the spirit of the activities for valorising the product and the territory: "Guérande: a landscape, a trade, a product". This model of salt marsh inspired the reactivation of other similar historical sites devoted to salt production in other parts of Europe and America. However, deficits with regard to local governance often hinder these valorisation strategies. In this sense, Renard (2016, this issue) investigates the case of the Zapotitlán Salinas saltworks in Mexico: strong historical, cultural and identity roots have not been sufficient with regard to obtaining a better price on the market, because of the inability of local stakeholders to develop a territorial governance that would allow them to valorise their resources.

An example of re-creation of new territorial food identities based on farm diversification is that of Jämtland, Sweden. Rytkonen (2016, this issue) highlights how a LAFS was enhanced by saving the remnants of traditional goat farming in a remote rural area in the North of the country. During the 1980 s, a collective action was initiated to add value to traditional agriculture by means of a diversified neo-patrimonialisation strategy: it included 


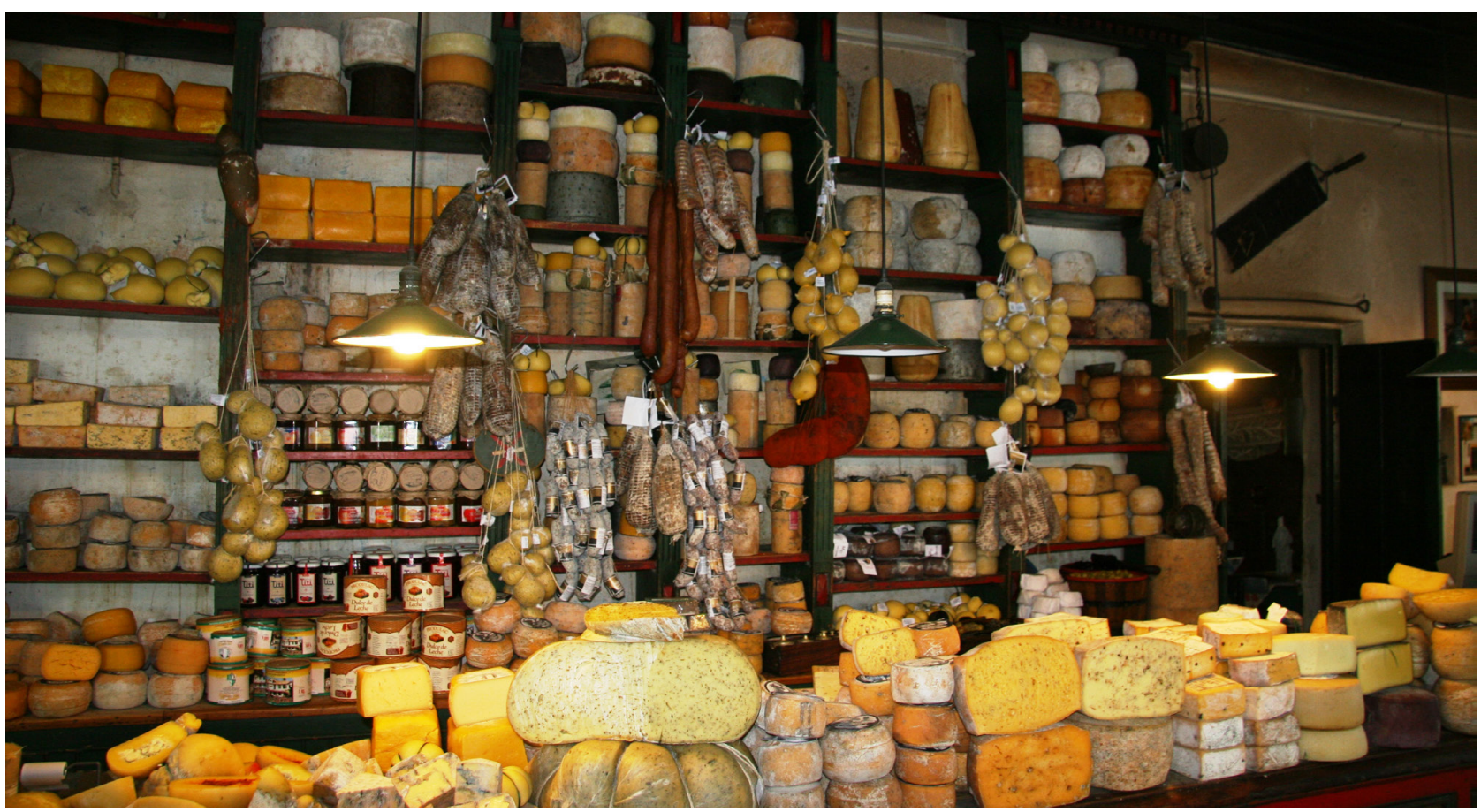

Рното 9. Cheese shop on the Tandil Cheese Route, province of Buenos Aires, Argentina.

the startup of small-scale goat farms, artisanal cheese units, sales at the farm, other short chains and rural tourism initiatives - farm cafes, bed \& breakfast lodgings, etc. As a result, a successful development programme won national recognition, had positive spillover effects on other Swedish rural areas, and generated locally positive territorial externalities.

In relation to environmental externalities, it should first be mentioned that the contribution of LAFS to maintaining farming in less favoured areas can be considered as a first positive one, as it combats farm abandonment and, consequently, depopulation in remote rural areas. The conservation of native plant varieties or breeds enhanced by many GIs contributes to generating a territorial externality, because protection of local genetic heritage is beneficial not only to local populations but even at a much broader geographical scale. Moreover, cooperatives and Regulatory Boards develop programmes in the Mediterranean EU, in partnership with public agencies and local institutions, on collective dissemination and training for the use of plant cover or for maintaining terraces in cultures on steep slopes, as effective methods for combating erosion; plant covers are currently recommended in sloping olive orchards or vineyards, not only to combat the loss of soils and fertility, but also because the negative effects of soil erosion and fertility loss spread to the surrounding territory (reservoir silting, etc.). Other cooperative programmes intended to fight diffused pollution in agriculture or to re-use agricultural or agro-industrial waste are also beneficial to large natural ecosystems, such as river basins.

Moreover, GIs, as a result of their links to specific local resources, can potentially play a positive role in envi-

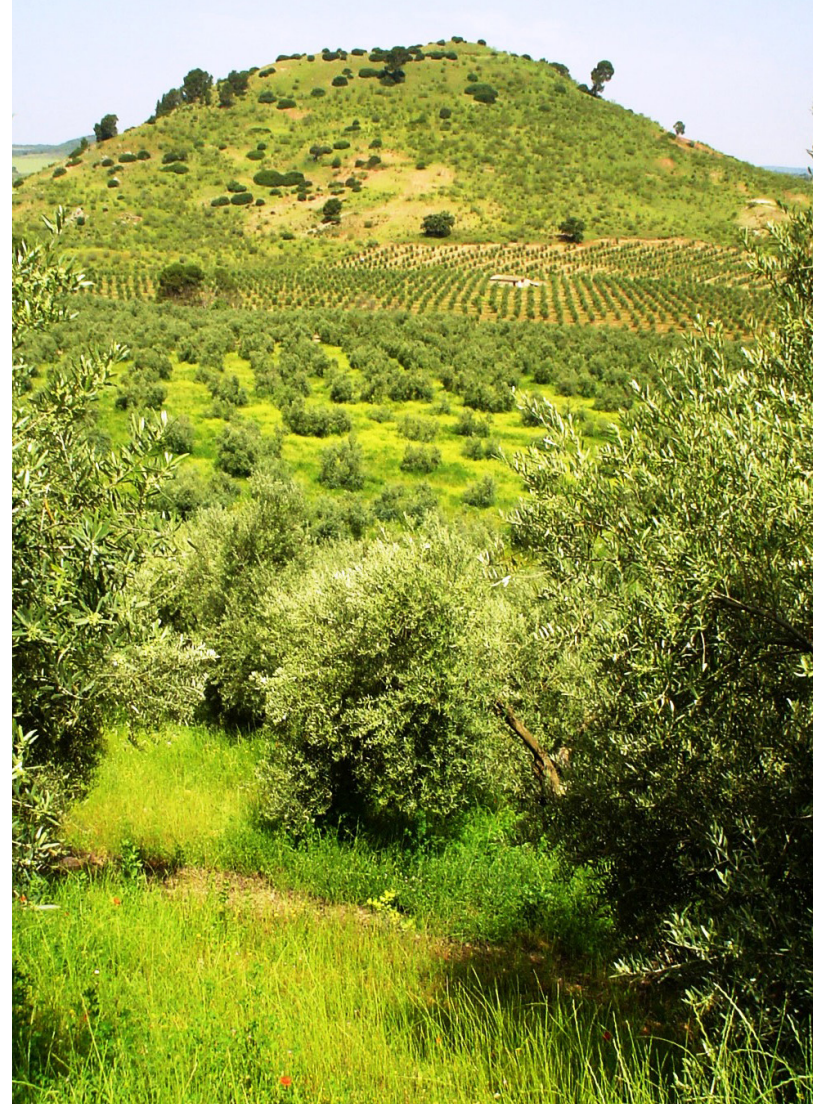

Рното 10. Landscape of mountain olive groves cultivated with plant cover: Sierra de Segura PDO, Andalusia, Spain. 
ronmental conservation, although the label cannot be considered as an environmental tool "per se". Preserving autochthonous varieties and breeds or traditional farming systems can appear explicitly in the product specifications. As a result, GIs can provide the opportunity for territorialising environmental-friendly production regulations, taking local specificities into account. Belletti et al. (2015) investigate the relationships between GIs and the environment, analysing the product specifications of all the 107 olive-oil GIs registered in the EU. Although environmental concerns are not considered to a great extent in the product specifications of many GIs, the results show a "greening" tendency over time; the most commonplace rules involve the use of rare native varieties and maximum production limits per hectare.

In any case, protection of geographical origins can maintain and promote cultural biodiversity, consequently generating environmental externalities for the whole region and even beyond. Bérard et al. (2005) analyse the links between biodiversity and protection of origin for a good number of cases in France that entail protecting, conserving and valorising local natural knowledge. A number of French PDOs, such as the Puy green lentil, the Espelette red pepper, the Paimpol bean and the Cévennes sweet onion, provide a description of the varied types of native varieties included in the product specifications; furthermore, they all mention that producers can use the seeds produced on their farm, which is a way to manage agro-biodiversity at the farm level. ${ }^{19}$ The "regional natural park" quality territorial label in France, involving agro-food products, other local artisanal products, and even tourism services, need to include three main guidelines in their specifications: production linked to the territory, protection and valorisation of the environment, and involvement of a human dimension. ${ }^{20}$ Thus, the strategy of protecting both origin and biodiversity can include a landscape dimension in GIs.

\section{CONCLUDING REFLECTIONS}

Research on LAFS arises from analysis of the diversity of relationships between food and territory. During the last two decades, a specific theoretical and empirical framework has been established in an effort to understand the anchorage and governance, as well as the effects on rural development, of a range of productive, socio-economic and cultural activities related to local food products and their terroirs. Research on origin of food products, based upon a historical and bio-cultural analysis of food identity, as well as on geographical and organisational proximity, which in turn focuses on a socio-cultural and economic approach to collective action, are key issues in LAFS studies.

With regard to origin, the intense relationships between agriculture and food processing, on one hand, and territory, environment and rural societies, on the other, together with their varied historical trajectories, determine the multiplicity of specific territorial resources - natural, cultural and socio-institutional ones - influencing food identity. New cultural-hybrid food identities are continuously being created worldwide, because territorial anchorage of food evolves over time and space. In LAFS theories, terroir is addressed as a "region-resource", as an ensemble of interrelated territorial specific assets, and not just as a place for the localisation of economic activities - a "region-support" focus on territory.

Moreover, organisational proximity is a potentiality for rural and territorial development. Specific resources of local food heritage are not only considered as factors generating differentiation attributes of food products, but also as specific assets that can be valorised both commercially on the markets and by creating common and public goods. The LAFS bases its efficiency on local governance of socio-economic and cultural networks linked territorially by means of the collective action of farms, agro-industrial firms, production services, auxiliary industries, retailers and institutions.

From a policy perspective, LAFS can contribute to counterbalancing the de-localisation tendencies affecting many commodity agro-food products on globalised markets. On these mass-markets, the price competitiveness strategies of leading retailing and agribusiness companies are continuously seeking territories, particularly in labour-intensive productions, where labour and other costs are cheaper. Patrimonialisation and valorisation of food identity becomes a sustainable survival strategy with regard to withstanding the de-localisation tendencies of agricultural products. Rural development policies promoting food anchorage are particularly appropriate in remote rural areas and in low-yield agricultural regions, such as numerous mountain or desert areas in America and Europe.

Another main policy issue is based on the following argument: as LAFS can contribute locally to producing common goods - innovation and knowledge, capacities, symbolic capital, etc. - and public goods - agricultural landscapes, gastronomic heritage, keeping the population in rural areas, territorial reputation, etc.- it is socially and politically accepted to reward local stakeholders on the basis of their contribution to both kinds of goods. Local social preferences in relation to environment, cultural heritage or rural development must be taken into account in the design of territorial policies.

Finally, studies on LAFS propose integrating methodologies and concepts influenced by complementary scientific approaches coming from the human, social and natural sciences. Research on LAFS, as a study objective, first implies taking into account the term "system" which defines them. LAFS result from complex interactions among different types of variables, such as territorial dynamics, food cultures or the physical and natural environment. To put it another way, these systems involve history, insolation, soils, rainfall, animals, plants..., as well as human beings and their institutions, co-operations and conflicts. Investigation on LAFS therefore requires, more than anything else, a perspective, a vision - the "Aleph", as Jorge Luis Borges would put it-, and the place from where one can contemplate this complex reality. This ap- 
proach requires the focus of different scientific disciplines: a trans-disciplinary view that enables us to comprehend the emergence and evolution over centuries of these foodstuffs, these food-based identities forming part of the cultural identities characterising human beings. These identities cannot be dissolved in the so-called "globalisation processes", but rather, should be accentuated by it. It is perhaps the time for enhancing mutual understanding among geographers, economists, sociologists, anthropologists, historians, environmentalists and agronomists.

\section{ACKNOWLEDGEMENTS}

This article is supported by the research project of the Spanish RDI National Plan: Local Agro-food Systems and public goods. Analysis and valuation models of territorial externalities in designations of origin of olive oil (EXTERSIAL II; Ref.: AGL2012-36537), coordinated by Dr. Javier Sanz-Cañada.

\section{NOTES}

1 Commodities are undifferentiated agricultural raw materials and products, or first elaboration agro-industrial goods, which are commercialized in bulk on the global mass-markets.

2 Research loosely grouped under the Alternative Agro-Food Networks (AAFN) rubric (Goodman et al., 2012; Marsden, 2004; Parrott et al., 2002; Tregear, 2011; Watts et al., 2005), belonging to the Anglo-American schools of Agro-food Geography, work on short-chain networks and local foods, consumer-sponsored agriculture, quality and multifunctionality. Both schools, LAFS and AAFN, draw from many of the same theoretical and empirical bases. A comparison of similarities and differences of both schools appears in Bowen and Mutersbaugh (2014).

3 See the Introduction to the special issue.

4 We speak specifically about Regional Economics, Economic Geography, Rural Sociology and Economic Anthropology.

5 Other approaches which are scientifically close to the above mentioned theories are those referring to "Clusters", "Diffuse Industrialisation" and "Innovative Milieus".

6 Although research, economic activities and policies on identitybased foods and territories have spread worldwide, the examples appearing in the paper fundamentally refer to America and Europe, in accordance with the thematic of the special issue. Although most of the scientific contributions came until recent times from France and from other European Mediterranean countries, Latin American research has decidedly been developed in the last decade: see, for instance, the compilations made by Boucher (2012), by Boucher et al. (2012) and by TorresSalcido and Larroa-Torres (2012).

7 The French concept of "terroir" has been translated variously as "territoriality", "connection to territory" or "place-based affinity". As Barham (2003: 128) notes, "no English word conveys the nuances and cultural depth of this French term, which is institutionally expressed in the PDO labelling process". A compilation of contributions regarding the meanings and approaches to terroir, as well as its methodological use, and numerous case studies, are set forth in Delfosse (2011) and in Bérard and Marchenay (2004).

8 http://whc.unesco.org/en/list/ 3 Feb. 2016

9 Local inter-professional organisations are institutions that associate members from various levels of the local supply-chain of a food product: farmers, raw-materials processing industries, industries manufacturing final products, distributors and retailers, among others.
10 The generic denomination "consumer groups" refers to a whole series of institutions at international level: "AMAP" in France, "supported community agriculture" in the Anglo Saxon world, "gruppi di acquisti solidale" in Italy, "consumer groups" and "consumer cooperatives" in Spain, etc.

11 In France, chocolate first appeared in Versailles in the XVII ${ }^{\text {th }}$ century, in the court of Louis XIV. His wife, Maria Teresa of Austria, organised get-togethers in which women chatted over hot chocolate.

12 According to EU legislation, a PDO covers agricultural products and foodstuffs in which all the phases of the food production chain are located in one given geographical area using recognised know-how. However, to achieve a PGI label it is only required that at least one of the different stages of agricultural production or processing is located in the area. See the definitions of PDO and PGI in Marescotti and Belletti (2016, this issue).

13 See, for instance: Bérard and Marchenay (2004); Barham and Sylvander (2011); ITC (2009); Lecoent et al. (2010); Tekelioglu et al. (2009); Vandecandelaere et al. (2010).

$14 \mathrm{http}: / /$ ec.europa.eu/agriculture/quality/door/list.html 1 Feb. 2016.

15 Governance is a form of government involving in the political decision-taking process multiple independent private and public stakeholders, who are coordinated in a non-hierarchical manner and who present multiple interactions and mutual agreements, as opposed to hierarchical government decisions only involving the State.

16 Vertical relationships involve links among stakeholders in different phases of the food chain (i.e., between farmers and industries), whereas horizontal relations are the ties among agents in the same phase of the chain or with other development agents (i.e., between farmers and development groups).

17 http://www.slowfood.com 8 Feb 2106. See in Petrini (2009) the philosophy, ideological fundamentals and lines of action of Slow Food movement.

18 See in Muchnik and Sainte-Marie (2010) a compilation of contributions on the relationships between collective organisation in LAFS, on the one hand, and techniques and knowledge, on the other.

19 Sainte-Marie, C. de and Bérard, L. Comment les savoirs locaux sont-ils pris en compte dans l'AOC ?; in Bérard et al. (2005): 188.

20 Adam, S. La marque "Parc naturel régional"; in Bérard et al. (2005): 207-208.

\section{REFERENCES}

Baptista, A.; Cristóvão, A.; Rodrigo, I.; Tibério, M.L. and VilasBoas, D. (2013) "Selling directly fresh and local products, looking at a new localized rurality: the case of PROVE Project”. Spanish Journal of Rural Development, 4 (4): 23-34.

Barham, E. (2003) "Translating terroir: the global challenge of French AOC labeling". Journal of Rural Studies, 19: 127-138.

Barham, E. and Sylvander, B. (eds.) (2011) Labels of origin for food. Local development, global recognition. $\mathrm{CAB}$ International, Oxfordshire (UK).

Becattini, G. (1979) "Dal settore industriale al distretto industriale. Alcune considerazioni sull'unitá di indagine dell'economia industriale". Rivista di Economia e Politica Industriale, 5 (1): 7-21.

Belletti, G. and Marescotti, A. (2011) "Origin Products, Geographical Indications and Rural Development”. In Labels of origin for food. Local development, global recognition edited by Barham, E. and Sylvander, B. CAB International, Oxfordshire (UK): 75-91.

Belletti, G.; Marescotti, A.; Sanz-Cañada, J. and Vakoufaris, H. (2015) "Linking protection of geographical indications to the environment: evidence from the European Union olive-oil sector". Land Use Policy, 48: 94-106.

Benko, G. and Desbiens, C. (2004) "French Economic Geography: introduction to the special issue". Economic Geography, 80 (4): 323-327. 
Benko, G. and Lipietz, A. (eds.) (1992) Les régions qui gagnent. Districts et réseaux; les nouveaux paradigmes de la Géographie Économique. Presses Universitaires de France, Paris.

Bérard, Laurence; Montel, Marie-Christine; Agabriel, Claire and Bouche, Rémi (2016) "Salers Protected Designation of Origin cheese (France). The diversity and paradox of local knowledge in geographical indications". Culture \& History Digital Journal, 5 (1): e006. doi: http://dx.doi.org/10.3989/chdj.2016.006, this issue.

Bérard, L.; Cegarra, M.; Djama, M.; Louafi, S.; Marchenay, Ph.; Roussel, B. and Verdeaux, F. (eds.) (2005) Biodiversité et savoirs naturalistes locaux en France. CIRAD, IDDRI, IFB and INRA, Montpellier and Paris.

Bérard, L. and Marchenay, Ph. (2004) Les produits du terroir. Entre cultures et règlements. Ed. CNRS, Paris.

Beyer, M.A. (2011) "Del grano al chocolate: la producción de una golosina mundial". Revista Digital Universitaria, UNAM, 12 (4): www.revista.unam.mx/vol.12/num4/art40/art40.pdf.

Boucher, F. (ed.) (2012) "Los Sistemas Agroalimentarios Localizados en América Latina". Agroalimentaria, special section, 18 (34): 73-144

Boucher, F.; Espinoza-Ortega, A. and Pensado-Leglise, M.R. (eds.) (2012) Sistemas agroalimentarios localizados en América Latina. Alternativas para el desarrollo territorial. Ed. Miguel Ángel Porrúa, México D.F.

Bowen, S. and Mutersbaugh, T. (2014) "Local or localized? Exploring the contributions of Franco-Mediterranean agrifood theory to alternative food research". Agriculture and Human Values, 31: 201-213.

Brusco, S. (1982) "The Emilian model: productive decentralisation and social integration". Cambridge Journal of Economics, 6 (2): 167-184

Casabianca F.; Sylvander, B.; Noel, Y.; Béranger C.; Coulon J.B. and Roncin F. (2005) "Terroir et typicité: deux concepts-clés des appellations d'origine contrôlées. Essai de définitions scientifiques et opérationnelles". In Symposium international "Territoires et enjeux du développement régional”. Lyon.

Cendón, M.L.; Sanz-Cañada, J. and Lucena-Piquero, D. (2014) "Differential quality and technical / managerial advice relationships in olive oil protected designations of origin". Spanish Journal of Agricultural Research, 12 (4): 869-888.

Chazoule, C. and Lambert, R. (2011) "Ancrage territoriale et formes de valorisation des productions localisés au Québec". Économie Rurale, 322: 11-23.

Chiffoleau, Y. and Touzard, J.M. (2014) "Understanding local agrifood systems through advice network analysis". Agriculture and Human Values, 31: 19-32.

Courlet, C. (2002) "Les Systèmes Productifs Localisés. Un bilan de la littérature". Etudes et Recherches sur les Systèmes Agraires et Développement, 33: 27-40.

Courlet, C. and Pecqueur, B. (1996) "Districts industriels, systèmes productifs localisés et développement". In Les nouvelles logiques $d u$ développement, edited by Abdelmalki, L. and Courlet, C. L'Harmattan, Paris: 91-101.

Courlet, C. and Pecqueur, B. (2013) L'Économie Territoriale. Presses Universitaires de Grenoble.

Crespo, J.; Requier-Desjardins, D. and Vicente, J. (2014) "Why can collective action fail in local agri-food systems? A social network analysis of cheese producers in Aculco, Mexico". Food Policy, 46: 165-177.

Csergo, J. (2011) "La emergencia de las cocinas regionales". In Historia de la Alimentación, edited by Flandrin, J.L. and Montanari, M. Ed. Trea (2nd ed.), Gijón: 1003-1024.

Deffontaines, J.P. (2005) "Paysages et agriculture dans les Alpes du Nord: représentations et aspirations de la société". Natures, Sciences et Sociétés, 13 (2): 214-215.

Delfosse, C. (ed.) (2011) La mode du terroir et les produits alimentaires. Ed. Les Indes Savantes, Paris.

Elverdín, J.H.; Maggio, A. and Muchnik, J. (2011) "Facteurs d'ancrage territorial des activités agricoles". Economie Rurale, 322: 64-78.
Fourcade, C.; Muchnik, J. and Treillon, R. (eds.) (2010) Coopérations, territoires et entreprises agroalimentaires. Ed. Quae, Paris.

Frayssignes, J. (2001) "L'ancrage territorial d'une filière fromagère d'AOC. L'exemple du système Roquefort'. Économie Rurale, 264-265: 89-103.

Garufi-Aglamisis, J.A. (2014) Procesos de construcción de la reputación territorial en producciones agroalimentarias localizadas del Occidente andaluz: Castilleja de la Cuesta e Isla Cristina. $\mathrm{PhD}$ Thesis, Universidad de Sevilla.

Goodman, D.; DuPuis, E.M. and Goodman, M.K. (2012) Alternative Food Networks: knowledge, practice and politics. Routledge, London and New York.

Guzmán Álvarez, José Ramón (2016) "The image of a tamed landscape: dehesa through History in Spain". Culture \& History Digital Journal, 5 (1): e003. doi: http://dx.doi.org/10.3989/ chdj.2016.003. this issue.

International Trade Centre (ITC) (2009) Guide to Geographical Indications. Linking products and their origins. ITC, Geneva.

Lambert-Derkimba, A.; Verrier, E. and Casabianca, F. (2011) "Tensions entre ressources génétiques locales et ancrage territorial des produits. La race porcine corse dans un projet AOP". Économie Rurale, 322: 39-49.

Lecoent, A.; Vandecandelaere E. and Cadilhon, J.J. (eds). (2010) Quality linked to geographical origin and geographical indications: lessons learned from six case studies in Asia. Food and Agriculture Organization, Bangkok.

Marescotti, Andrea and Belletti, Giovanni (2016) "Differentiation strategies in coffee global value chains through reference to territorial origin in Latin American countries". Culture \& History Digital Journal, 5 (1): doi: http://dx.doi.org/10.3989/chdj.2016.007, this issue.

Marsden, T. (2004) "The quest for ecological modernisation: respacing Rural Development and Agri-Food studies". Sociologia Ruralis, 44 (2): 129-146.

Mendez, A. and Mercier, D. (2005) "Trajectoires territoriales et "empreinte" de 1'histoire: le cas de Grasse et de la Ciotat en Région PACA". Géographie, Économie et Société, 7: 347-363.

Minvielle, P.; Consales, J.L. and Daligaux, J. (2011) "Le système AMAP, l'émergence d'un SYAL métropolitain". Économie Rurale, 322: $50-63$.

Montanari, M. (2013) L'identità italiana in cucina. Ed. Laterza, Bari.

Muchnik, J. (2006) "Identidad territorial y calidad de los alimentos: procesos de calificación y competencias de los consumidores". Agroalimentaria, 22: 86-98.

Muchnik, J. and Sainte-Marie, C. de (eds.) (2010) Le temps des Syal: techniques, vivres et territoires. Ed. Quae, Paris.

Muchnik, J.; Sanz-Cañada, J. and Torres-Salcido, G. (2008) "Systèmes Agroalimentaires Localisés: état des recherches et perspectives". Cahiers d'Études et des Recherches Francophones / Agricultures, 17 (6): 513-519.

Organisation for Economic Cooperation and Development (OECD) (2006) The new rural paradigm: policies and governance. Ed. OECD, Paris

Parrott, N.; Wilson, N. and Murdoch, J. (2002) "Spatializing quality: regional protection and the Alternative Geography of Food". European Urban and Regional Studies, 9 (3): 241-261.

Pecqueur, B. (2001) "Qualité et développement territorial: l'hypothèse du panier de biens et de services territorialisés". Économie Rurale, 261: 37-49.

Petrini, C. (2009) Terra Madre. Come non farci mangiare dal cibo. Giunti and Slow Food Editore, Bra and Firenze.

Praly, C.; Chazoule, C.; Delfosse, C. and Pluvinage, J. (2007) "SYAL et relocalisation des agricultures européennes: une application à l'arboriculture de la Moyenne Vallée du Rhône", Économies et Sociétés, série "Systèmes agroalimentaires", 29: 1547-1566.

Rallet, A. (2002) "L'économie des proximités. Propos d'étape". Études et Recherches sur les Systèmes Agraires et Développement, 33: 11-25. 
Renard, Marie-Christine and Thomé Ortiz, Humberto (2016) "Cultural heritage and food identity: The pre-Hispanic salt of Zapotitlán Salinas, Mexico". Culture \& History Digital Journal, 5 (2): e004. doi: http://dx.doi.org/10.3989/chdj.2015.004, this issue.

Rytkönen, Paulina (2016) "Local resources, foreign influences, value creation, tradition and modernity. The case of a Local Agro-food System in Jämtland, Sweden". Culture \& History Digital Journal, 5 (1): e009. doi: http://dx.doi.org/10.3989/chdj.2016.009, this issue.

Saavedra Gallo, Gonzalo and Macías Vázquez, Alfredo (2016) "Collective action and symbolic capital in the artisanal fisheries: An analysis of the Local Food Systems of Reloncaví Estuary (Los Lagos), Chile". Culture \& History Digital Journal, 5 (1): e005. doi: http://dx.doi.org/10.3989/chdj.2016.005, this issue.

Sanz-Cañada (2009) "Les appellations d'origine protégée d'huile d'olive en Espagne. Systèmes agroalimentaires localisés, gouvernance et externalités territoriales". Options Méditerranéens, 89: $237-254$

Sanz-Cañada, J. and Macías-Vázquez, A. (2005) “Quality certification, institutions and innovation in local agro-food systems: protected designations of origin of olive oil in Spain". Journal of Rural Studies, 21: 475-486.

Sanz-Cañada, J. and Muchnik, J. (eds.) (2011) “Ancrage et identité territoriale des systèmes agroalimentaires localisés. Introduction au dossier". Économie Rurale, 322: 4-10.

Scholliers, P. (2009) "Novedad y tradición. El nuevo panorama de la gastronomía". In Gastronomía. Historia del paladar, edited by Freedman, P. Publicacions Universitat de València (PUV): 333-357.

Tekelioglu, Y.; Ilbert, H. and Tozanli, S. (eds.) (2009) "Les produits de terroir, les indications géographiques et le développement local durable des pays méditerranéens". Options Méditerranéens, 89: 5-381.
Torre, A. and Filippi, M. (eds.) (2005) Proximités et changements socio-économiques dans les mondes ruraux. Ed. INRA, Paris.

Torre, A.; Galliano, D. and Rama, R. (2013) "Localisation et ancrage territorial des firmes agroalimentaires. Introduction au dossier thématique". Économies et Sociétés, série "Systèmes Agroalimentaires", 35: 1997-2008.

Torres-Salcido, G. and Larroa-Torres, R.M. (eds.) (2012) Sistemas agroalimentarios localizados. Identidad territorial, construcción de capital social e instituciones. Ed. Universidad Nacional Autónoma de México, México D.F.

Torres-Salcido, Gerardo; Ramos-Chávez, Alejandro and UrretaFernández, Álvaro (2016) "Bio-cultural anchorage of the prickly pear cactus in Tlalnepantla (Morelos), Mexico". Culture \& History Digital Journal, 5 (1): e008. doi: http://dx.doi. org/10.3989/chdj.2016.008, this issue.

Tregear, A. (2011) "Progressing knowledge in alternative and local food networks: Critical reflections and a research agenda". Journal of Rural Studies, 27 (4): 419-430.

Trubek, A.B. (2008) The taste of place. A cultural journey into terroir. University of California Press, Berkeley and Los Angeles.

Valceschini, E. (1999) "Les signaux de qualité crédibles sur les marchés agroalimentaires: certifications officielles et marques". In Signes officiels de qualité et développement agricole, edited by Lagrange, L. Ed. Technique \& Documentation, Paris: 147-166.

Vandecandelaere, E.; Arfini, F.; Belletti, G. and Marescotti, A. (eds.) (2010) Linking people, places and products. Food and Agriculture Organization, Rome.

Watts, D.C.H.; Ilbery, B. and Maye, D. (2005) "Making reconnections in Agro-Food Geography: alternative systems of food provision”. Progress in Human Geography, 29 (1): 22-40. 